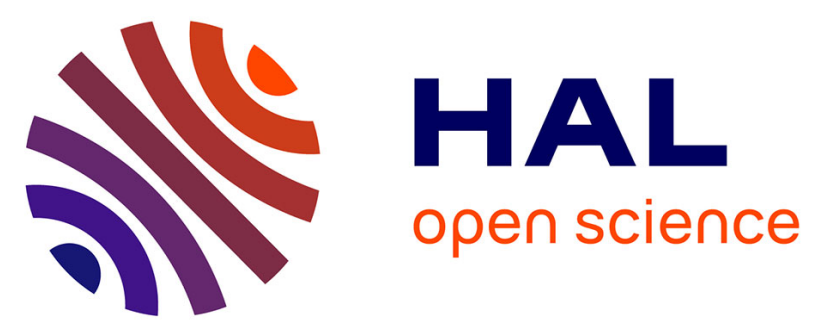

\title{
Mononuclear iron(II) complexes containing a tripodal and macrocyclic nitrogen ligand: synthesis, reactivity and application in cyclohexane oxidation catalysis
}

Massinissa Ayad, Robertus J.M. Klein Gebbink, Yves Le Mest, Philippe P. Schollhammer, Nicolas Le Poul, François Pétillon, Dominique Mandon

\section{To cite this version:}

Massinissa Ayad, Robertus J.M. Klein Gebbink, Yves Le Mest, Philippe P. Schollhammer, Nicolas Le Poul, et al.. Mononuclear iron(II) complexes containing a tripodal and macrocyclic nitrogen ligand: synthesis, reactivity and application in cyclohexane oxidation catalysis. Dalton Transactions, 2018, 47 (43), pp.15596-15612. 10.1039/C8DT02952K . hal-01885668

\section{HAL Id: hal-01885668 \\ https://hal.univ-brest.fr/hal-01885668}

Submitted on 25 Nov 2020

HAL is a multi-disciplinary open access archive for the deposit and dissemination of scientific research documents, whether they are published or not. The documents may come from teaching and research institutions in France or abroad, or from public or private research centers.
L'archive ouverte pluridisciplinaire HAL, est destinée au dépôt et à la diffusion de documents scientifiques de niveau recherche, publiés ou non, émanant des établissements d'enseignement et de recherche français ou étrangers, des laboratoires publics ou privés. 


\section{Journal Name}

\section{ARTICLE}

\section{Mononuclear iron(II) complexes containing a tripodal and macrocyclic nitrogen ligand: synthesis, reactivity and application in cyclohexane oxidation catalysis ${ }^{\ddagger}$}

Received 00th January 20xx, Accepted 00th January 20xx

DOI: $10.1039 / x 0 x \times 00000 x$

www.rsc.org/
Massinisa Ayad, ${ }^{a}$ Robertus J. M. Klein Gebbink, ${ }^{b}$ Yves. Le Mest, ${ }^{a}$ Philippe Schollhammer, ${ }^{a}$ Nicolas Le Poul, ${ }^{* a}$ François Y. Pétillon ${ }^{a}$ and Dominique Mandon ${ }^{\text {ta }}$

\section{Introduction}

Most of oxidation reactions are catalysed in nature by iron enzymes. ${ }^{1-3}$ On one hand, heme-enzymes such as cytochrome P450 have been extensively studied because of their ubiquitous role in many reactions occurring in plants, bacteria and animals. ${ }^{4-6}$ The large number of in-depth studies have led to the characterization of several reactive iron-oxygen adducts, such as iron-hydroperoxo and iron-oxo species, which have inspired chemists for the development of synthetic model complexes based on heme-like ligands, such as porphyrins, phtalocyanins or corroles. ${ }^{7,8}$ On the other hand, non-heme iron enzymes have generated a particular interest for the last twenty years. ${ }^{9-13}$ Among them, mononuclear Rieske dioxygenases $^{14-16}$ and dinuclear soluble methane monooxygenases (sMMO) $)^{3,9,17-19}$ have been widely investigated because these enzymes can perform hydroxylation of aromatic and aliphatic hydrocarbons, respectively. Most of mononuclear non-heme iron enzymes

\footnotetext{
UMR CNRS 6521, Laboratoire de Chimie, Electrochimie Moléculaires et Chimie Analytique, Université de Bretagne Occidentale, 6 Avenue Victor Le Gorgeu, CS 93837, 29238 Brest Cedex 3, France.

Email: francois.petillon@univ-brest.fr; nicolas.lepoul@univ-brest.fr

${ }^{b .}$ Organic Chemistry and Catalysis, Faculty of Science, Universiteit Utrecht, Utrecht, The Netherlands.

+ Deceased in July 2016

$¥$ Article dedicated in the memory of Pr. Jacques E. Guerchais, who deceased in April 2018.

Electronic Supplementary Information (ESI) available: [UV-Vis spectroscopic and Xray data]. CCDC 1856876, 1856877 and 1856878. See DOI: 10.1039/x0xx00000x
}

display two histidine residues and labile water molecules in their active site, the coordination sphere being completed by aspartate or glutamate groups, known as the 2-His-1carboxylate triad. $^{13,14}$ For instance, the naphthalene 1,2dioxygenase catalyzes the cis-hydroxylation of naphthalene by reaction of a pentacoordinated $\mathrm{Fe}(\mathrm{II})$ centre with $\mathrm{O}_{2}$. The reaction occurs through the formation of putative $\mathrm{Fe}^{\mathrm{V}}(\mathrm{O})(\mathrm{OH})$ adducts resulting from $\mathrm{O}-\mathrm{O}$ bond cleavage of hydroperoxo

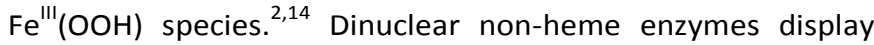
another mode of processing catalytic oxidations. ${ }^{9}$ Hence, sMMOs are characterized at their resting state in their active site by a $\left[\mathrm{Fe}^{\prime \prime \prime}{ }_{2}(\mu-\mathrm{OH})_{2}\right]$ cluster surrounded by glutamate and histidine moieties. At the (II,II) reduced state, reaction with $\mathrm{O}_{2}$ leads to the formation of transient iron-oxygen species. Among them, the "diamond core" bis- $\mu$-oxo $\mathrm{Fe}^{\mathrm{IV}}{ }_{2}$ ("Q $\mathrm{Q}$ ) was shown to be one key active species performing the oxidation of methane into methanol. ${ }^{1,2,17}$ Recent works on particulate methane monooxygenases (pMMOs) have emphasized the importance of the MMOB (methane monooxygenase B) subunit in the catalytic process for both triggering substrate and dioxygen transport through the protein pores and inhibiting further reduction of the generated $\mathrm{Fe}_{2} \mathrm{O}_{2}$ cluster. $^{3}$

Many synthetic models of non-heme iron enzymes have been developed for almost thirty years in order to obtain efficient catalysts for hydrocarbon oxidation. ${ }^{2,7,9,18}$ Different ligand architectures have been proposed according to the targeted transient mononuclear or dinuclear iron-oxygen species. Among them, two examples of widely studied monotopic ligand families can be mentioned, namely the tripodal 
tetradentate TPA moiety (TPA = tris (methylpyridine) amine) and the multidentate macrocyclic cyclam or TACN series (cyclam = tetraazacyclotetradecane, TACN = triazacyclononane). Hence, Que et al., reported in 1999 the first crystallographic evidence of a "diamond core" $\mathrm{Fe}^{\mathrm{IV}} \mathrm{Fe}^{\mathrm{III}}(\mu-$ $\mathrm{O}){ }_{2}$ complex by appropriated design of a TPA ligand (5$\left.\mathrm{Et}_{3} \mathrm{TPA}\right){ }^{20}$ Since then, many other monotopic TPA-based ligands have been described, leading to mono- or bis-iron complexes. ${ }^{9,21}$ Alternatively, monotopic cyclam-based ligands have also been widely developed. ${ }^{22-24}$ Structures of different mononuclear iron-oxygen adducts ( $\mathrm{Fe}^{\mathrm{III}}$ peroxo and $\mathrm{Fe}^{\mathrm{IV}}$ oxo) were obtained with the $\mathrm{N}$-substituted cyclam derivative. ${ }^{22,24-26}$ Concomitantly, Costas and co-workers investigated the iron chemistry of $\mathrm{N}$-substituted TACN ligands. ${ }^{2,27}$ A mononuclear $\mathrm{Fe}^{\mathrm{V}}(\mathrm{O})(\mathrm{OH})$ adduct was characterized by mass spectrometry from the reaction of the $\left[\mathrm{Fe}^{\prime \prime}\left({ }^{\mathrm{Me}, \mathrm{HPy}} \mathrm{TACN}\right)(\mathrm{OTf})_{2}\right]$ complex (OTf $=$ triflate ion) with hydrogen peroxide. ${ }^{28}$

Chart 1

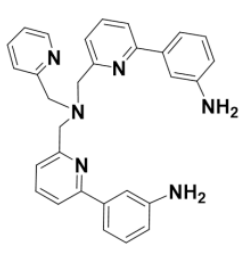

$L^{1}$

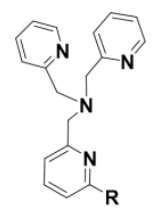

$R_{1}$ TPA

$(\mathrm{R}=\mathrm{Me}, \mathrm{Cl}, \mathrm{Br}, \mathrm{F}, \mathrm{I}, \mathrm{CN})$
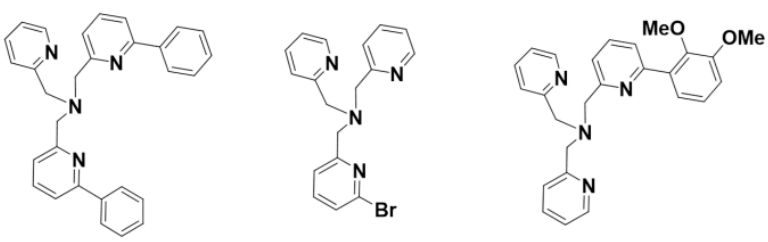

$\mathrm{Ph}_{2} \mathrm{TPA}\left(\mathrm{L}^{\mathrm{a}}\right)$

$\operatorname{BrTPA}\left(\mathrm{L}^{\mathrm{b}}\right)$

(OMe)2PhTPA

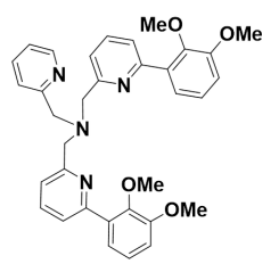

(OMe)2 $\mathrm{Ph}_{2}$ TPA

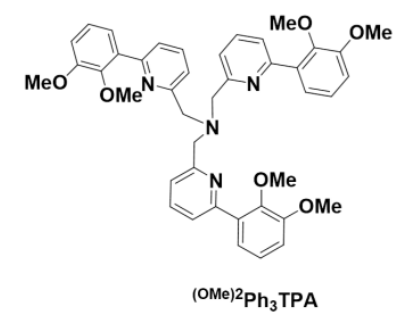

Since other high-valent species have been identified, and the role of water upon formation of such species has been emphasized ("water-assisted mechanism"). ${ }^{2,9}$ Ditopic ligands have also been designed in order to mimic the active site of sMMO. ${ }^{18,29-33}$ These are based on pincer-type moieties in order to adjust the Fe-Fe distance by bridging groups (carboxylate, benzoate..). For instance, Kodera and co-workers used a bis-TPA frame in order to obtain a high-spin $(S=2)$ $\mathrm{Fe}^{\mathrm{IV}}{ }_{2}(\mu-\mathrm{O})$ adduct. $^{34}$ Alternatively, Lippard et al. synthesised pre-organized macrocyclic ditopic ligand bearing two phenoxylimine (PIM) coordinating cores. $^{35,36}$ These latter authors showed very recently that the redox properties of the bis-iron complexes could be tuned by suitable introduction of a carboxylate group in the PIM moiety. ${ }^{37}$ For all these model complexes, many parameters have been varied in order to rationalize the effect of the ligand topology on the catalytic properties. $^{2,9,38}$ Hence, high-spin iron complexes displaying labile ligands in cis-position and high redox potential have been targeted. High reactivity was obtained from high-spin $(S=2)$ mononuclear $\mathrm{Fe}^{\mathrm{IV}}$-oxo species generated by using bulky tripodal moieties and weak-field equatorial ligands. ${ }^{39}$ Inspired by recent works on the structural models of sMMO developed by Lippard and co-workers, we have focused our research on the development of a macrocyclic ligand which could display one or two coordination sites for metal ions. By taking advantage of our previous work on TPA-derivatives and their mononuclear complexes, ${ }^{40-50}$ we have designed a novel ligand $\mathbf{L}^{\mathbf{2}}$ (Chart 1 ) which displays two different coordinating cores, namely TPA and pyridine-dicarboxamide (PydCA). Such dissymmetrical ditopic ligand may indeed coordinate one or several metal ions, leading to the formation of homo or heteronuclear dinuclear complexes as recently reported for analogous macrocyclic ligands. ${ }^{51-53}$ We thus present here the synthesis and characterization of the ligand $\mathbf{L}^{2}$ and its precursor $\mathbf{L}^{1}$ (Chart 1 ). As first results, we have focused our work on mononuclear iron(II) complexes 1-4 derived from these two ligands, and scrutinized the effect of the counter-ion (chloride, triflate), as well as the topology of the ligand on the structural properties and reactivity toward oxidants $\left(\mathrm{O}_{2}, \mathrm{H}_{2} \mathrm{O}_{2}\right.$, m-chloroperoxybenzoic acid (mCPBA)) in absence and presence of a hydrogenated substrate (cyclohexane). A comparison with analogous iron complexes bearing TPAderived ligands (Chart 1 ) has been carried out to better account for the effects of the ligand architecture on the catalytic properties.

\section{Experimental section}

\section{General procedures}

All air sensitive organic reactions, as well as the handling and synthesis of iron complexes were routinely carried out under an argon atmosphere using standard Schlenk techniques. Further manipulations were performed in an MBraun UNILab sp glovebox workstation under an argon atmosphere, unless otherwise pointed out. Solvents were either distilled immediately before use under nitrogen from appropriate drying agents or passed through an MBraun MB SPS-800 solvent purification system. All dry solvents were degassed 
before use by bubbling $\mathrm{N}_{2}$ through the liquid for $30 \mathrm{~min}$ or by freeze-thaw with nitrogen liquid under strict anaerobic conditions. Methanol was rigorously dried with $\mathrm{Mg}$ turnings; $\mathrm{CH}_{2} \mathrm{Cl}_{2}$ (electrochemistry) was freshly distilled from $\mathrm{CaH}_{2}$ and kept under $\mathrm{Ar}$ in the glovebox. The precursors 2-methyl -6 bromo-pyridine, ${ }^{54}$ 6-bromo-2-(bromomethyl) pyridine, ${ }^{55}$ bis $\{(6-$ bromo-2-pyridyl)methyl\} (2-pyridylmethyl)amine, ${ }^{45,56,57}$ were prepared according to previously described methods. All other reagents were purchased from Sigma-Aldrich and used without purification. Column chromatography was performed using silica gel $(60-200 \mu \mathrm{m}, 60 \AA)$ or neutral activated aluminum oxide (50-160 $\mathrm{mm})$.

\section{Physical Methods}

Infrared spectra were recorded on a Bruker-Vertex 70- Avatar spectrometer for solids. Chemical analyses were performed either by the 'Service de Microanalyse' ICSN-CNRS of Gif/Yvette (France) or by the "Service Central d'Analyse" of Vernaison (France). The UV-Vis measurements were carried out on a Jasco V- $650(190-1000 \mathrm{~mm})$ spectrophotometer or a Varian Cary 05 E UV-VIS NIR spectrophotometer equipped with an Oxford instrument DN 1704 cryostat in optically transparent Schlenk cells. NMR spectra were recorded in $\mathrm{CDCl}_{3}, \mathrm{CD}_{3} \mathrm{CN}$ or $\mathrm{CD}_{2} \mathrm{Cl}_{2}$ at ambient temperature on a Bruker $\mathrm{AC}$ $500\left({ }^{1} \mathrm{H},{ }^{13} \mathrm{C}\right)$, AC $400\left({ }^{1} \mathrm{H},{ }^{13} \mathrm{C},{ }^{31} \mathrm{P}\right)$, or AC $300\left({ }^{1} \mathrm{H},{ }^{13} \mathrm{C},{ }^{31} \mathrm{P},{ }^{19} \mathrm{~F}\right)$ spectrometer, according to the sample that was analyzed; the signals are indicated as follows: chemical shift (ppm), intensity, multiplicity, and coupling constants $(J, \mathrm{~Hz})$. EPR spectra were obtained from a Bruker Elexsys E500 spectrometer, at a perpendicular mode $X$ band $(9.62 \mathrm{GHZ})$; simulations were performed using the Bruker Spin-Count software. Electrochemical studies of the complexes were performed in a glovebox (Jacomex) $\left(\mathrm{O}_{2}<1 \mathrm{ppm}, \mathrm{H}_{2} \mathrm{O}<1 \mathrm{ppm}\right)$ with a homedesigned 3-electrodes cell (WE: glassy carbon, RE: Pt wire in a $\mathrm{Fc}^{+} / \mathrm{Fc}$ solution, $\mathrm{CE}$ : Pt or graphite rod). Ferrocene was added at the end of the experiments to determine redox potential values. The potential of the cell was controlled by an AUTOLAB PGSTAT 100 (Metrohm) potentiostat monitored by the NOVA software. HPLC-grade acetonitrile was degased under argon and stored into the glovebox. Dichloromethane was distilled over $\mathrm{CaH}_{2}$ before being stored in a glovebox. The supporting salt $\mathrm{NBu}_{4} \mathrm{PF}_{6}$ was synthesized from $\mathrm{NBu}_{4} \mathrm{OH}$ (Acros) and $\mathrm{HPF}_{6}$ (Aldrich). It was then purified, dried under vacuum for 48 hours at $100^{\circ} \mathrm{C}$, then kept under argon in the glovebox. Conductivity measurements were carried out under argon at $20^{\circ} \mathrm{C}$ in $\mathrm{CH}_{3} \mathrm{CN}$ with a CDM 210 Radiometer Copenhagen Conductivity Meter using a Tacussel XE 150507569 electrode; the procedure used for the complexes was the following: $4 \mathrm{~mL}$ of dry and degasified acetonitrile were introduced into the cell and the relative conductivity of the bank was measured (A), then the relative conductivity of the sample in $\mathrm{CH}_{3} \mathrm{CN}$ was determined (B), giving the conductivity values of the complex by subtraction (B-A/concentration). Mass Spectrometric measurements were performed on an Autoflex MALDI TOF III LRF200 spectrometer by the "Service Commun de Spectrométrie de Masse" of the University of Bretagne
Occidentale (Brest). ESI-MS spectrometry was recorded on a Waters LCT Premier XE KE317 Micromass Technologies spectrometer at Debye Institute for Nanomaterials Science, Faculty of Science, Utrecht University, The Netherlands. GC analysis was performed with a Perkin-Elmer Clarus 500 Gas Chromatography equipped with an Agilent HP-5 column (30m $\times 0.32 \mathrm{~mm} \times 0.25 \mu \mathrm{m}$ ) and a flame-ionization detector at Debye Institute for Nanomaterials Science (Utrecht), The Netherlands.

\section{Synthesis of the ligands}

$\mathbf{L}^{1}$. The ligand $\mathbf{L}^{1}$ was synthesized according to the Suzuki crosscoupling procedure. ${ }^{57-59}$ To a mixture of $500 \mathrm{mg}(1.12 \mathrm{mmol})$ of bis $\left\{\right.$ (6-bromo-2-pyridyl)methyl\}(2-pyridylmethyl)amine ( $\alpha-\mathrm{Br}_{2}$ TPA) and $174 \mathrm{mg}(1.12 \mathrm{mmol})$ of $\left[\mathrm{Pd}\left(\mathrm{PPh}_{3}\right)_{4}\right]$ in $100 \mathrm{~mL}$ of degassed toluene, was added $10 \mathrm{~mL}$ of a $0.1 \mathrm{M}$ solution of $\mathrm{K}_{2}\left(\mathrm{CO}_{3}\right)$, and 2.5 eq. of 2-aminophenyl boronic acid $(363 \mathrm{mg}$, $2.35 \mathrm{mmol}$ ) in suspension in $10 \mathrm{~mL}$ of degassed ethanol. The mixture, kept under an argon atmosphere, was heated to reflux at $120^{\circ} \mathrm{C}$ and stirred for $48 \mathrm{~h}$. Then, the solution was evaporated to dryness to give a pale-yellow oil. The residue was taken up from $\mathrm{CH}_{2} \mathrm{Cl}_{2}$ and washed several times with aqueous $\mathrm{K}_{2}\left(\mathrm{CO}_{3}\right)$, and then with water. The organic layer was dried over magnesium sulfate, and then concentrated. Addition of pentane gave a brown residue, which was dissolved in $\mathrm{CH}_{2} \mathrm{Cl}_{2}$. This procedure was repeated three times. Thus, the resulting brown oil turned out to be the clean product $\mathrm{L}^{1}\left(\mathrm{C}_{30} \mathrm{H}_{28} \mathrm{~N}_{6}\right)$. Yield $320 \mathrm{mg}(60 \%) .{ }^{1} \mathrm{H}-\mathrm{NMR}(400 \mathrm{MHz}$, $\left.\mathrm{CDCl}_{3}, \delta\right): 8.47(\mathrm{~d}, J=5.6 \mathrm{~Hz}, 1 \mathrm{H}), 7.69-7.64(\mathrm{~m}, 6 \mathrm{H}), 7.55(\mathrm{t}, J=4.4$ $\mathrm{Hz}, 5 \mathrm{H}), 7.48\left(\mathrm{dt}, J^{3}=7.6 \mathrm{~Hz}, J^{4}=2.8 \mathrm{~Hz}, 1 \mathrm{H}\right), 7.39(\mathrm{t}, J=2.0 \mathrm{~Hz}$, $1 \mathrm{H}), 7.32(\mathrm{~d}, J=7.6 \mathrm{~Hz}, 2 \mathrm{H}), 7.13(\mathrm{t}, J=4.8 \mathrm{~Hz}, 1 \mathrm{H}), 6.71\left(\mathrm{dd}, J^{3}=\right.$ $\left.7.6 \mathrm{~Hz}, J^{4}=0.8 \mathrm{~Hz}, 1 \mathrm{H}\right), 4.01(\mathrm{~s}, 4 \mathrm{H}), 4.00(\mathrm{~s}, 2 \mathrm{H}), 3.74(\mathrm{~s}, 4 \mathrm{H}) .{ }^{13} \mathrm{C}-$ $\mathrm{NMR}\left(75.46 \mathrm{MHz}, \mathrm{CDCl}_{3}, \delta\right): 161.2\left(C_{\text {ipso }}\right), \quad 160.6\left(C_{\text {ipso }}\right)$, $158.1\left(C_{i p s o}\right), 150.4(\mathrm{CH}), 148.3\left(C_{\text {ipso }}\right), 141.9\left(C_{\text {ipso }}\right), 138.3\left(C_{\text {ipso }}\right)$, $137.8(\mathrm{CH}), \quad 133.5(\mathrm{CH}), \quad 133.4(\mathrm{CH}), \quad 129.9(\mathrm{CH}), \quad 129.8(\mathrm{CH})$, $129.6(\mathrm{CH}), \quad 124.3(\mathrm{CH}), \quad 123.3(\mathrm{CH}), \quad 122.5(\mathrm{CH}), \quad 120.1(\mathrm{CH})$, $118.5(\mathrm{CH}), 117.0(\mathrm{CH}), 115.0(\mathrm{CH}), 61.8\left(2 \mathrm{C}, \mathrm{C}_{\text {meso }}, \mathrm{N}-\mathrm{CH}_{2}-\mathrm{Py}\right)$, 61.7(1C, $\left.\mathrm{C}_{\text {meso, }} \mathrm{N}-\mathrm{CH}_{2}-\mathrm{Py}\right)$.

$\mathbf{L}^{\mathbf{2}}$. The ligand $\mathbf{L}^{\mathbf{2}}$ was synthesized according to the slightly modified method of Holm et al. ${ }^{52}$ To a dried THF $(500 \mathrm{~mL})$ solution of $\mathrm{Et}_{3} \mathrm{~N}$ ( $3 \mathrm{~mL}, 40$ eq.) was added simultaneously a THF solution $(50 \mathrm{~mL})$ of 2,6-pyridine dicarbonylchloride $(260 \mathrm{mg}$, $1.27 \mathrm{mmol}$ ), and 2-aminophenyl-6-methylpyridine $(500 \mathrm{mg}$, $1.05 \mathrm{mmol}$ ) in THF/acetonitrile $(50 \mathrm{~mL}, 4 / 1)$ drop by drop over $3 \mathrm{~h}$. The mixture was refluxed at $120^{\circ} \mathrm{C}$ for 3 days, and filtered. Then, the volatiles were evaporated to give a brown oil, which was dissolved in dichloromethane $(10 \mathrm{~mL})$ and dried over $\mathrm{MgSO}_{4}$. After filtration and evaporation of the solvent, the product was purified by crystallization in dichloromethane/pentane (5/95) to give $\mathrm{L}^{2}\left(\mathrm{C}_{37} \mathrm{H}_{29} \mathrm{~N}_{7} \mathrm{O}_{2}\right)$ as a light brown powder. Yield $325 \mathrm{mg}(51 \%)$. IR (solid, $\mathrm{cm}^{-1}$ ): $\mathrm{v}(\mathrm{NH})$ 3313(w), v(C=O) 1681(s). ${ }^{1} \mathrm{H}-\mathrm{NMR}\left(400 \mathrm{MHz}, \mathrm{CDCl}_{3}, \delta\right): 10.31(\mathrm{~s}$, $2 \mathrm{H}), 8.61(\mathrm{~d}, J=6.5 \mathrm{~Hz}, 2 \mathrm{H}), 8.56(\mathrm{~d}, J=8.0 \mathrm{~Hz}, 1 \mathrm{H}), 8.14(\mathrm{t}, J=8.0$ $\mathrm{Hz}, 1 \mathrm{H}), 7.70(\mathrm{t}, J=7.6 \mathrm{~Hz}, 3 \mathrm{H}), 7.55(\mathrm{~m}, 10 \mathrm{H}), 7.31(\mathrm{~d}, J=7.0 \mathrm{~Hz}$, $3 \mathrm{H}), 6.99(\mathrm{t}, J=5.6 \mathrm{~Hz}, 1 \mathrm{H}), 4.17(\mathrm{~s}, 4 \mathrm{H}), 4.13(\mathrm{~s}, 2 \mathrm{H}) .{ }^{13} \mathrm{C}-\mathrm{NMR}$ $\left(75.46 \mathrm{MHz}_{\mathrm{CDCl}}, \delta\right): 161.1(2 \mathrm{C}, \quad \mathrm{C}=\mathrm{O}), 159.3\left(2 \mathrm{C}, C_{\mathrm{ipso}}\right)$, 
158.0(2C, $\left.C_{\text {ipso }}\right), 156.2(2 \mathrm{C}, C=\mathrm{O}), 148.4\left(2 \mathrm{C}, C_{\mathrm{ipso}}\right), 148.2(1 \mathrm{C}, \mathrm{CH})$, 139.6(2C, $\left.C_{\text {ipso }}\right), 138.3(1 \mathrm{C}, \mathrm{CH}), 137.2\left(2 \mathrm{C}, C_{\text {ipso }}\right), 136.7(2 \mathrm{C}, \mathrm{CH})$, $135.8(1 \mathrm{C}, \mathrm{CH}), 128.7(2 \mathrm{C}, \mathrm{CH}), 122.5(1 \mathrm{C}, \mathrm{CH}), 124.9(2 \mathrm{C}, \mathrm{CH})$, $121.9(2 \mathrm{C}, \mathrm{CH}), 121.3(2 \mathrm{C}, \mathrm{CH}), 120.1(1 \mathrm{C}, \mathrm{CH}), 119.4(2 \mathrm{C}, \mathrm{CH})$, 118.9(4C, $\mathrm{CH}), 61.6\left(2 \mathrm{C}, \mathrm{C}_{\text {meso }}, \mathrm{N}-\mathrm{CH}_{2}-\mathrm{Py}\right), 59.8\left(1 \mathrm{C}, \mathrm{C}_{\text {meso }}, \mathrm{N}-\mathrm{CH}_{2}-\right.$ Py). ESI-MS $\left(\mathrm{CHCl}_{3}, \mathrm{~m} / \mathrm{z}\right)$ : Calcd. for [M]: 603.31. Found: 602.13 assigned to $[\mathrm{M}-\mathrm{H}]^{+}$.

\section{Synthesis of iron(II) complexes}

$\left[\mathrm{FeCl}_{2}\left(\mathbf{L}^{1}\right)\right]$ (1). To a yellow-brown solution of $\mathbf{L}^{1}(80 \mathrm{mg}, 0.17$ mmol) in dry, degassed $\mathrm{CH}_{3} \mathrm{CN}(5 \mathrm{~mL})$ was added a light-yellow suspension of anhydrous $\mathrm{FeCl}_{2}(20.4 \mathrm{mg}, 0.16 \mathrm{mmol}$ ) in acetonitrile $(5 \mathrm{~mL})$ at room temperature; upon addition, the solution coloured to orange. The reaction mixture was stirred for $8 \mathrm{~h}$ and then concentrated under reduced pressure. Addition of $\mathrm{Et}_{2} \mathrm{O}(30 \mathrm{~mL})$ afforded a green solid, which was washed with $\mathrm{Et}_{2} \mathrm{O}(3 \times 10 \mathrm{~mL})$, and then dried under vacuum to give 1 as a dark-green powder. Yield $73 \mathrm{mg}$ (76\%). ${ }^{1} \mathrm{H}-\mathrm{NMR}$ (400 MHz, $\mathrm{CD}_{2} \mathrm{Cl}_{2}, \delta$ ) (ppm): 119.2(s-br, $\left.1 \mathrm{H}, \mathrm{CH}_{\alpha(\mathrm{Pyr})}\right)$, 86.1(s-br, $\left.2 \mathrm{H}, \mathrm{CH}_{2}\right), 53.8\left(\mathrm{~s}, 1 \mathrm{H}, \mathrm{CH}_{\beta, \beta^{\prime}(\mathrm{Pyr})}\right), 51.2\left(\mathrm{~s}, 1 \mathrm{H}, \mathrm{CH}_{\beta, \beta^{\prime}(\mathrm{Pyr})}\right), 32.2(\mathrm{~s}-\mathrm{br}$, $\left.2 \mathrm{H}, \mathrm{CH}_{2}\right), 17.3\left(\mathrm{~s}-\mathrm{br}, 2 \mathrm{H}, \mathrm{CH}_{2}\right), 7.3\left(\mathrm{~m}, 3 \mathrm{H}, \mathrm{CH}_{\gamma(\mathrm{Pyr})}\right), 3.9(\mathrm{~s}-\mathrm{br}, 1 \mathrm{H}$, $\left.\mathrm{CH}_{\chi \text { (Pyr) })}\right), 1.3\left(\mathrm{~s}, 2 \mathrm{H}, \mathrm{NH}_{2}\right), 1.1\left(\mathrm{~s}, 2 \mathrm{H}, \mathrm{NH}_{2}\right), 0.57(\mathrm{~s}-\mathrm{br}, 3 \mathrm{H}$, uncoord.Pyr). UV-Vis (MeCN) $\lambda_{\max }, \mathrm{nm} \quad\left(\varepsilon, \mathrm{M}^{-1} \mathrm{~cm}^{-1}\right)$ : 257(18550), 285(14500), 324(8160). ESI-MS $\left(\mathrm{CH}_{3} \mathrm{CN}, \mathrm{m} / \mathrm{z}\right)$ : Calcd for $\left[\mathrm{FeCl}\left(\mathbf{L}^{1}\right)\right]^{+}:$563.14. Found: 563.13.

$\left[\mathrm{FeCl}_{2}\left(\mathrm{~L}^{2}\right)\right]$ (2). To an acetonitrile $(10 \mathrm{~mL})$ solution of $\mathrm{L}^{2}(100 \mathrm{mg}$, $0.16 \mathrm{mmol}$ ) was added, under argon, $20 \mathrm{mg}(0.16 \mathrm{mmol})$ of anhydrous $\mathrm{FeCl}_{2}$ in degassed $\mathrm{CH}_{3} \mathrm{CN}(10 \mathrm{~mL})$. The mixture was stirred overnight and then concentrated under reduced pressure. Addition of diethyl ether afforded a yellow-brown powder. Crystals suitable for an X-ray analysis were formed by slow vapour diffusion of $\mathrm{Et}_{2} \mathrm{O}$ into a $\mathrm{CH}_{2} \mathrm{Cl}_{2}$ solution of $\mathbf{2}$ in a sealed tube. Yield $73 \mathrm{mg}(62 \%)$. Anal. found: $\mathrm{C}=58.31, \mathrm{H}=3.87$, $\mathrm{N}=12.43 \%$. Anal. calcd for $\mathrm{C}_{37} \mathrm{H}_{29} \mathrm{Cl}_{2} \mathrm{FeN}_{7} \mathrm{O}_{2}, 1.5 \mathrm{H}_{2} \mathrm{O}$ (757.08): $\mathrm{C}=58.65, \mathrm{H}=4.26, \mathrm{~N}=12.94 \%$. IR (solid, $\mathrm{cm}^{-1}$ ): $\mathrm{v}(\mathrm{NH}) 3446(\mathrm{w})$, $v(\mathrm{CO})$ 1683(s). ${ }^{1} \mathrm{H}-\mathrm{NMR}$ (300 MHz, $\mathrm{CD}_{3} \mathrm{CN}, \delta$ ) (ppm): 102.2(svbr, $\left.1 \mathrm{H}, \mathrm{CH}_{\alpha(\mathrm{Pyr})}\right), 53.7\left(\mathrm{~s}-\mathrm{vbr}, 2 \mathrm{H}, \mathrm{CH}_{2}\right), 45.7\left(\mathrm{~s}, 1 \mathrm{H}, \mathrm{CH}_{\beta, \beta^{\prime}(\mathrm{Pyr})}\right)$, 42.4(s, $\left.1 \mathrm{H}, \mathrm{CH}_{\beta, \beta^{\prime}(\mathrm{Pyr})}\right), 38.4\left(\mathrm{~s}-\mathrm{vbr}, 2 \mathrm{H}, \mathrm{CH}_{2}\right), 33.3\left(\mathrm{~s}-\mathrm{br}, 2 \mathrm{H}, \mathrm{CH}_{2}\right)$, 29.9(s,2H, $\left.\mathrm{CH}_{\beta, \beta^{\prime}(\mathrm{Pyr})}\right), 11.7\left(\mathrm{~s}, 1 \mathrm{H}, \mathrm{CH}_{\chi(\mathrm{Pyr})}\right), 7.9\left(\mathrm{~m}, 8 \mathrm{H}, \mathrm{CH}_{(\text {Phenyl }}\right.$ subst. $), 3.9\left(\mathrm{~s}, 1 \mathrm{H}, \quad \mathrm{CH}_{\gamma(\mathrm{Pyr})}\right), 2.7(\mathrm{~s}), 0.35(\mathrm{~s})$ and $-2.7(\mathrm{~s})(6 \mathrm{H}$, $\left.\mathrm{CH}_{\left.\beta, \beta^{\prime \prime}, \chi \text { (uncord.Pyr }\right)}\right),-8.7(\mathrm{~s}, 2 \mathrm{H}, \mathrm{NH})$. UV-Vis $\left(\mathrm{CH}_{2} \mathrm{Cl}_{2}\right) \lambda_{\text {max }}, \mathrm{nm}(\varepsilon, \mathrm{M}$ $\left.{ }^{1} \mathrm{~cm}^{-1}\right)$ : 253(10500), 341(3280), 386(1785). ESI-MS $\left(\mathrm{CHCl}_{3}\right.$, $\mathrm{m} / \mathrm{z})$ : calcd for $\left[\mathrm{FeCl}\left(\mathrm{L}^{2}\right)\right]^{+}:$694.62. Found: 694.66. Molecular conductivity $\left(C=1.5 \mathrm{mM}, \mathrm{CH}_{3} \mathrm{CN}\right): \Lambda=24 \mathrm{~S} \mathrm{~cm}^{2} \mathrm{~mol}^{-1}$. Magnetic moment (Evan's method) ${ }^{60-61 .}: \mu_{\text {eff }}=1.52 \mu \mathrm{B}$.

[Fe'"I $\left.(\mathrm{OH})\left(\mathrm{OL}^{\mathbf{2}^{\prime}}\right)\right]_{2}\left[\left(\mathrm{FeCl}_{3}\right)_{2}(\boldsymbol{\mu}-\mathrm{O})\right], \mathbf{3 C H}_{3} \mathrm{CN}\left(\mathbf{2}^{\prime}\right) ; \mathrm{L}^{\mathbf{2}^{\prime}}=\mathrm{L}^{\mathbf{2}}-1 \mathrm{H}_{\mathrm{Ph}}$. To an acetonitrile $(3 \mathrm{~mL})$ solution of $2(8 \mathrm{mg}, 0.01 \mathrm{mmol})$ were added 10 eq. of $\mathrm{H}_{2} \mathrm{O}_{2}(33 \%)$ in $\mathrm{CH}_{3} \mathrm{CN}$. After stirring a few minutes, the colour turned from yellow-brown to red-orange. The solvent was then removed giving small amounts of $\mathbf{2}^{\prime}$ as a red-orange powder, which was recrystallized by slow diffusion of $\mathrm{Et}_{2} \mathrm{O}$ into an acetonitrile solution of 2' giving, after several days, single crystals suitable for X-ray analysis. EPR $(9.30 \mathrm{GHz}$, $\left.\mathrm{CH}_{3} \mathrm{CN}, 150 \mathrm{~K}\right)$ : silent.

$\left[\mathrm{Fe}\left(\mathrm{CH}_{3} \mathrm{CN}\right)\left(\mathrm{L}^{1}\right)\right](\mathrm{OTf})_{2}$ (3). A white suspension of [Fe(OTf $\left.)_{2}\right]$ (71.2 $\mathrm{mg}, 0.20 \mathrm{mmol}$ ) in dry, degassed $\mathrm{CH}_{3} \mathrm{CN}(5 \mathrm{~mL})$ was added to an acetonitrile $(5 \mathrm{~mL})$ solution of $\mathbf{L}^{1}(100 \mathrm{mg}, 0.21$ $\mathrm{mmol}$ ) under argon, at room temperature. Upon addition, the reaction mixture coloured to red-orange. After stirring for $8 \mathrm{~h}$, a red-brown solid was formed. The solvent was removed by cannula filtration and the product was washed with $\mathrm{Et}_{2} \mathrm{O}(3 \mathrm{x}$ $10 \mathrm{~mL}$ ), dried in vacuum to give 3 as a red-orange powder. Crystals suitable for an $\mathrm{X}$-ray analysis were obtained by slow vapor diffusion of $\mathrm{Et}_{2} \mathrm{O}$ into a $\mathrm{CH}_{3} \mathrm{CN}$ solution of $\mathbf{3}$, in a sealed tube. Yield $86 \mathrm{mg}$ (52\%). IR (solid, $\mathrm{cm}^{-1}$ ): v(NH) 3360(s), v(CF) 1026(s). ${ }^{1} \mathrm{H}-\mathrm{NMR}(400 \mathrm{MHz}, \delta)(\mathrm{ppm}): 120.1\left(\mathrm{~s}-\mathrm{vbr}, 1 \mathrm{H}, \mathrm{CH}_{\alpha(\mathrm{Pyr})}\right)$, 61.4(s-br, $\left.2 \mathrm{H}, \mathrm{CH}_{2}\right), 60.7\left(\mathrm{~s}-\mathrm{br}, 3 \mathrm{H}, \mathrm{CH}_{\beta, \beta^{\prime}(\mathrm{Pyr})}\right), 59.1(\mathrm{~s}-\mathrm{br}, 2 \mathrm{H}$, $\mathrm{CH}_{2}$ ), 46.5(s-br, 3H, $\left.\mathrm{CH}_{\beta, \beta^{\prime}(\mathrm{Pyr})}\right), 20.6\left(\mathrm{~s}-\mathrm{vbr}, 3 \mathrm{H}, \mathrm{CH}_{\gamma(\mathrm{Pyr})}\right), 11.5(\mathrm{~s}-\mathrm{br}$, $\left.3 \mathrm{H}, \mathrm{CH}_{\text {(Phenyl subst.) }}\right), 7.3\left(\mathrm{~m}-\mathrm{br}, 3 \mathrm{H}, \mathrm{CH}_{\text {(Phenyl subst.) })}, 5.45(\mathrm{~s}, 2 \mathrm{H}\right.$, $\left.\mathrm{CH}_{\text {(Phenyl subst.) }}\right), 3.6\left(\mathrm{~s}, 3 \mathrm{H}, \mathrm{CH}_{3} \mathrm{CN}\right),-9.8\left(\mathrm{~s}, 2 \mathrm{H}, \mathrm{CH}_{2}\right),-12.0(\mathrm{~s}, 4 \mathrm{H}$, $\left.\mathrm{NH}_{2}\right) .{ }^{19} \mathrm{~F}-\mathrm{NMR}\left(282.23 \mathrm{MHz}, \mathrm{CD}_{3} \mathrm{CN}, \delta\right)(\mathrm{ppm}):-78.2\left(\mathrm{~s}, \mathrm{CF}_{3}\right)$. UV-Vis (MeCN) $\lambda_{\text {max }}, \mathrm{nm}\left(\varepsilon, \mathrm{M}^{-1} \mathrm{~cm}^{-1}\right): 259(16300), 283(13360)$, 335(4880). ESI-MS $\left(\mathrm{CH}_{3} \mathrm{CN}, \mathrm{m} / \mathrm{z}\right)$ : Calcd for $\left[\mathrm{Fe}(\mathrm{OTf})\left(\mathrm{L}^{1}\right)\right]^{+}$: 677.12. Found: 677.10 .

$\left[\mathrm{Fe}\left(\mathrm{H}_{2} \mathrm{O}\right)_{2}\left(\mathrm{~L}^{2}\right)\right](\mathrm{OTf})_{2}, \quad 2 \mathrm{H}_{2} \mathrm{O}$ (4). An acetonitrile solution of [Fe(OTf) ${ }_{2}$ ] $(35.4 \mathrm{mg}, 0.10 \mathrm{mmol})$ was added to a $\mathrm{MeCN}(5 \mathrm{~mL})$ solution of $\mathbf{L}^{2}(100 \mathrm{mg}, 0.10 \mathrm{mmol})$. The mixture was stirred overnight and then filtered. The volume of solvent was reduced to $c a 1 \mathrm{~mL}$. Then, $\mathrm{Et}_{2} \mathrm{O}(10 \mathrm{~mL})$ was added to precipitate a solid. The solvent was removed by cannula filtration and the product was washed twice with $\mathrm{Et}_{2} \mathrm{O}(2 \times 5$ $\mathrm{mL}$ ), dried in vacuum to give the compound 4 as a red-orange solid. Yield $68 \mathrm{mg}(\sim 40 \%)$. IR (solid, $\left.\mathrm{cm}^{-1}\right): v(\mathrm{NH}) 3342(\mathrm{w})$, $v(\mathrm{CO}) 1680(\mathrm{~m}), v(\mathrm{CF})$ 1029(s). ${ }^{1} \mathrm{H}-\mathrm{NMR}$ (400 MHz, $\mathrm{CD}_{3} \mathrm{CN}, \delta$ ) (ppm): 62.4(s-vbr, $\left.1 \mathrm{H}, \mathrm{CH}_{\beta, \beta^{\prime}(\mathrm{Pyr})}\right), 46.9\left(\mathrm{~s}-\mathrm{br}, 1 \mathrm{H}, \mathrm{CH}_{\beta, \beta^{\prime}(\mathrm{Pyr})}\right)$, 38.2(s-vbr, 2H, CH 2 ), 33.0(s-vbr, 2H, $\mathrm{CH}_{2}$ ), 30.5(s-vbr, 2H, $\left.\mathrm{CH}_{\beta, \beta^{\prime}(\mathrm{Pyr})}\right), 11.7\left(\mathrm{~s}-\mathrm{vbr}, 2 \mathrm{H}, \mathrm{CH}_{2}\right), 10.8\left(\mathrm{~s}-\mathrm{br}, 2 \mathrm{H}, \mathrm{CH}_{\text {(Phenyl subst. })}\right)$, 9.2(s-br, $\left.2 \mathrm{H}, \mathrm{CH} \gamma_{(\mathrm{Pyr})}\right), 8.7\left(\mathrm{~s}-\mathrm{br}, 1 \mathrm{H}, \mathrm{CH} \gamma_{(\mathrm{Pyr})}\right), 8.3\left(\mathrm{~s}-\mathrm{br}, 1 \mathrm{H}, \mathrm{CH}_{(\mathrm{Phy}}\right.$

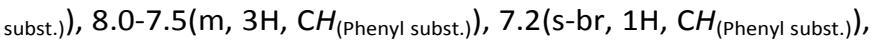
3.9(s-br, $1 \mathrm{H}, \mathrm{CH}_{\text {(Phenyl subst.) })}, 2.14\left(\mathrm{OH}_{(\mathrm{H} 2 \mathrm{O})}\right.$, obscured by $\mathrm{CH}_{3} \mathrm{CN}$ $\mathrm{CD}_{3} \mathrm{CN}$ ), $1.28\left(\mathrm{~s}-\mathrm{br}, 1 \mathrm{H}, \mathrm{CH}_{\text {(uncord.Pyr) }}\right),-0.32\left(\mathrm{~s}-\mathrm{br}, 2 \mathrm{H}, \mathrm{CH}_{\text {(uncord. }}\right.$ Pyr) ), - 2.86(s-br, 2H, NH$\left.H_{2}\right) .{ }^{19} \mathrm{~F}-\mathrm{NMR}\left(282.23 \mathrm{MHz}, \mathrm{CD}_{3} \mathrm{CN}, \delta\right)$ (ppm): - 79.6(s, $\left.\mathrm{CF}_{3}\right)$. UV-Vis (MeCN) $\lambda_{\max }, \mathrm{nm}\left(\varepsilon, \mathrm{M}^{-1} \mathrm{~cm}^{-1}\right)$ : 253(18100), 284(18600). ESI-MS $\left(\mathrm{CHCl}_{3}, \mathrm{~m} / \mathrm{z}\right)$ : Calcd for $\left[\mathrm{Fe}\left(\mathrm{H}_{2} \mathrm{O}\right)_{2}(\mathrm{OTf})\left(\mathrm{L}^{2}\right)\right]^{+}, 2 \mathrm{H}_{2} \mathrm{O}:$ 880.2. Found: 880.2. Molecular conductivity $\left(C=1.5 \mathrm{mM}, \mathrm{CH}_{3} \mathrm{CN}\right): \Lambda=138 \mathrm{~S} \mathrm{~cm}^{2} \mathrm{~mol}^{-1}$.

\section{X-ray structural determination}

Measurements for compounds 2, 2' and $\mathbf{3}$ were made on an Oxford Diffraction X-Calibur-2CDD diffractometer equipped with jet cooler device. Graphite-monochromated Mo $\mathrm{K} \alpha$ radiation $(\lambda=0.71073 \AA)$ was used in all experiments. The structures were solved and refined by standard procedures. ${ }^{62,63}$ Small crystals were obtained for 2'; therefore, they gave somewhat low-resolution diffraction patterns. However, the results of the diffraction analysis for this compound 2' provide sufficient proof of the proposed structure. A nitrogen stream cryostat attached to the system enabled low-temperature measurements (mainly at $170 \mathrm{~K}$ ). 


\section{Journal Name}

\section{ARTICLE}

Table 1 Crystal data and structure refinement for compounds 2, 2' and $\mathbf{3}$ at $170 \mathrm{~K}$.

\begin{tabular}{|c|c|c|c|}
\hline & 2 & $\mathbf{2}^{\prime}$ & 3 \\
\hline Empirical formula & $\mathrm{C}_{37} \mathrm{H}_{29} \mathrm{Cl}_{2} \mathrm{FeN}_{7} \mathrm{O}_{2}$ & $\mathrm{C}_{80} \mathrm{H}_{67} \mathrm{Cl}_{6} \mathrm{Fe}_{4} \mathrm{~N}_{17} \mathrm{O}_{9}$ & $\mathrm{C}_{34} \mathrm{H}_{31} \mathrm{~F}_{6} \mathrm{FeNN}_{7} \mathrm{O}_{6} \mathrm{~S}_{2}$ \\
\hline Formula weight & 730.42 & 1846.61 & 867.63 \\
\hline Temperature & $170(2) \mathrm{K}$ & $170(2) \mathrm{K}$ & $170(2) \mathrm{K}$ \\
\hline Wavelength & $0.71073 \AA$ & $0.71073 \AA$ & $0.71073 \AA$ \\
\hline $\begin{array}{l}\text { Crystal system, space } \\
\text { group }\end{array}$ & Monoclinic, Cc & Monoclinic, P21/m & Triclinic, P-1 \\
\hline \multirow[t]{6}{*}{ Unit cell dimensions } & $a=15.153(3) \AA ̊$ & $a=12.8448(6) \AA ̊$ & $a=11.6048(4) \AA ̊$ \\
\hline & $b=13.630(2) \AA$ & $b=24.3450(14) \AA$ & $\alpha=116.401(4)^{\circ}$. \\
\hline & $\beta=107.23(2)^{\circ}$. & $\beta=110.800(6)^{\circ}$ & $b=13.6563(6) \AA$ \\
\hline & $c=16.654(3) \AA$ & $c=13.5498(7) \AA$ & $\beta=92.178(3)^{\circ}$. \\
\hline & & & $c=14.1144(4) \AA$ \\
\hline & & & $\gamma=109.682(4)^{\circ}$ \\
\hline Volume & $3285.3(10) \AA^{3}$ & $3961.0(4) \AA^{3}$ & $1839.14(12) \AA^{3}$ \\
\hline Z, Calculated density & 4, $1.477 \mathrm{Mg} / \mathrm{m}^{3}$ & $2,1.548 \mathrm{Mg} / \mathrm{m}^{3}$ & $2, .1 .567 \mathrm{Mg} / \mathrm{m}^{3}$ \\
\hline Absorption coefficient & $0.669 \mathrm{~mm}^{-1}$ & $0.990 \mathrm{~mm}^{-1}$ & $0.610 \mathrm{~mm}^{-1}$ \\
\hline$F(000)$ & 1504 & 1888 & 888 \\
\hline Crystal description & Triangular rod, axis $\left[\begin{array}{lll}1 & 0 & 0\end{array}\right]$ & Rod, axis $\left[\begin{array}{lll}1 & 0 & 0\end{array}\right]$ & Fragment of plate \\
\hline Crystal colour & Colourless & Brown & Yellow \\
\hline Crystal size & $0.17 \times 0.06 \times 0.03 \mathrm{~mm}$ & $0.19 \times 0.07 \times 0.06 \mathrm{~mm}$ & $0.33 \times 0.18 \times 0.13 \mathrm{~mm}$ \\
\hline $\begin{array}{l}\text { Theta range for data } \\
\text { collection }\end{array}$ & 2.81 to $26.37^{\circ}$ & 3.31 to $26.37^{\circ}$ & 3.43 to $26.37^{\circ}$ \\
\hline Limiting indices & $\begin{array}{l}-14<=\mathrm{h}<=18 \\
-16<=\mathrm{k}<=17 \\
-20<=1<=20\end{array}$ & $\begin{array}{l}-15<=h<=16 \\
-20<=k<=30 \\
-16<==1<=16\end{array}$ & $\begin{array}{l}-12<=h<=14 \\
-17<=k<=10 \\
-17<=\mid<=17\end{array}$ \\
\hline $\begin{array}{l}\text { Reflections collected / } \\
\text { unique }\end{array}$ & $12174 / 4852[R($ int $)=0.200$ & $23434 / 8265[R($ int $)=0.1044]$ & $15152 / 7511[R($ int $)=0.0326]$ \\
\hline $\begin{array}{l}\text { Completeness to theta }= \\
26.37\end{array}$ & $99.8 \%$ & $99.7 \%$ & $99.7 \%$ \\
\hline Absorption correction & Analytical & Analytical & Analytical \\
\hline $\begin{array}{l}\text { Max. and min. } \\
\text { transmission }\end{array}$ & 0.9802 and 0.8948 & 0.9430 and 0.8341 & 0.9250 and 0.8242 \\
\hline Refinement method & Full-matrix least-squares on $\mathrm{F}^{2}$ & Full-matrix least-squares on $\mathrm{F}^{2}$ & Full-matrix least-squares on $\mathrm{F}^{2}$ \\
\hline $\begin{array}{l}\text { Data / restraints / } \\
\text { parameters }\end{array}$ & 4852 / 134 / 432 & 8265 / 41 / 591 & $7511 / 14$ / 506 \\
\hline Goodness-of-fit on $F^{2}$ & 0.822 & 1.026 & 1.054 \\
\hline Final $R$ indices & $R 1=0.0769$ & $\mathrm{R} 1=0.0749$ & $\mathrm{R} 1=0.0396$ \\
\hline$[\mid>2 \operatorname{sigma}(I)]$ & $w R 2=0.0771$ & $w R 2=0.1736$ & $w R 2=0.0982$ \\
\hline $\mathrm{R}$ indices (all data) & $\mathrm{R} 1=0.1888$ & $\mathrm{R} 1=0.1408$ & $\mathrm{R} 1=0.0524$ \\
\hline & $w R 2=0.0969$ & $\mathrm{R} 2=0.2199$ & $w R 2=0.1060$ \\
\hline Largest diff. peak and hole & 0.370 and -0.392 e. $A^{-3}$ & 1.127 and -0.572 e. $\mathrm{A}^{-3}$ & 0.471 and -0.458 e. $A^{-3}$ \\
\hline
\end{tabular}




\section{Journal Name}

\section{ARTICLE}

Intensity data were collected combining several runs (omegascan, step $1^{0}$ ) in order to get a complete set of reflections (as far as possible down to $d=0.8 \AA$ or less). Selected bond lengths, angles, data collection and processing parameters are given in Table 1 and in the Supporting Information.

\section{Catalytic oxidation of cyclohexane}

The catalytic properties of the iron(II) complexes for the room temperature oxidation of cyclohexane in presence of hydrogen peroxide or m-CPBA have been investigated by gaschromatography (GC). Experiments were performed with excess of substrate and oxidizing agent (vs catalyst) to avoid oxidation of solvent (MeCN) and over-oxidation of products. The quantitative determination of the main products, cyclohexanol (A) and cyclohexanone (K), was carried out by using acetophenone, as internal standard compound. Hence, the turnover number (moles of product/moles of catalysts), the alcohol/ketone concentration ratio $([\mathrm{A}] /[\mathrm{K}])$ and the total yield (moles of products/moles of oxidant) have been determined for each catalyst under the different experimental conditions. Additionally, control experiments under the same experimental conditions but without catalysts were performed. They evidenced that cyclohexane could not be oxidized without the iron(II) precursor.

\section{Results and discussion}

\section{Syntheses}

The ligands $\mathbf{L}^{\mathbf{1}}$ and $\mathbf{L}^{\mathbf{2}}$ were synthesized and characterized according to procedures similar to those reported previously $^{52,57-59}$ (see the Experimental section). Here, these two organic compounds acted either as tridentate or tetradentate ligands by the nature of the iron salt that was used as reactant. Tridentate and tetradendate coordination mode of the ligand was operative, respectively, with $\left[\mathrm{FeCl}_{2}\right]$ and $\left[\mathrm{Fe}(\mathrm{OTf})_{2}\right]$. Thus, treatment of $\left[\mathrm{FeCl}_{2}\right]$ with 1 eq. of $\mathbf{L}^{\mathbf{1}}$ in acetonitrile at room temperature, under inert conditions, resulted in a clear color change from pale-yellow to orange; after work-up the reaction product, a dark-green solid $\mathbf{1}$ was obtained in good yields. In a similar way, reaction of $\left[\mathrm{FeCl}_{2}\right]$ with $\mathbf{L}^{\mathbf{2}}$ gave compound $\mathbf{2}$ as a yellow-brown powder in valuable yields (see Scheme 1(a)). As shown below, both complexes $\mathbf{1}$ and $\mathbf{2}$ are neutral, whereas dicationic compounds 3 and 4 were synthesized by stirring a mixture of [ $\left.\mathrm{Fe}(\mathrm{OTf})_{2}\right]$ and the appropriate stoichiometric amount of $\mathbf{L}^{\mathbf{1}}$ or $\mathbf{L}^{\mathbf{2}}$ at room temperature (Scheme $1(\mathrm{~b}))$. The syntheses and reaction conditions are outlined in Scheme 1.

\begin{tabular}{|c|c|c|c|c|c|c|}
\hline & $1^{1}$ & 2 & 3 & 4 & {$\left[\mathrm{FeCl}_{2}\left(\mathrm{~L}^{\mathrm{a}}\right)\right]^{7}$} & {$\left[\mathrm{FeCl}_{2}\left(\mathrm{~L}^{\mathrm{b}}\right)\right]^{7}$} \\
\hline $\mathrm{CH}_{\alpha}(\mathrm{Py})$ & $119.2^{2,3}$ & $102.2^{2,3}$ & $120.1^{2,3}$ & & $120.0^{2,4}$ & $119.0^{2,4}$ \\
\hline \multirow[t]{3}{*}{$\mathrm{CH}_{2}$} & $86.1^{2,4}$ & $53.7^{2,3}$ & $61.4^{2,4}$ & $38.2^{2,4}$ & $88.0^{2,4}$ & $62.0^{2,4}$ \\
\hline & $32.2^{2,4}$ & $38.4^{2,3}$ & $59.1^{2,4}$ & $33.0^{2,4}$ & $31.0^{2,4}$ & $55.0^{2,4}$ \\
\hline & $17.3^{2,4}$ & $33.3^{2,4}$ & $-9.8^{2}$ & $11.7^{2,4}$ & $21.0^{2,4}$ & $31.0^{2,4}$ \\
\hline \multirow[t]{3}{*}{$\mathrm{CH}_{\beta, \beta^{\prime}}(\mathrm{Py})$} & $53.8^{2}$ & $45.7^{2}$ & $60.7^{2}$ & $62.4^{2,3}$ & $54.1^{2}$ & $51.1^{2}$ \\
\hline & $51.2^{2}$ & $42.4^{2}$ & $46.5^{2}$ & $46.9^{2,3}$ & $52.9^{2}$ & $44.4^{2}$ \\
\hline & & $29.9^{2}$ & & $30.5^{2,3}$ & & $23.3^{2}$ \\
\hline \multirow[t]{2}{*}{$\mathrm{CH}_{\gamma}(\mathrm{Py})$} & $7.3^{2,3}$ & $11.7^{2}$ & $20.6^{2,4}$ & $9.2^{2,4}$ & $7.5^{2,4}$ & $13.1^{2}$ \\
\hline & $3.9^{2,4}$ & $3.9^{2}$ & & $8.7^{2,4}$ & $4.5^{2,4}$ & $11.0^{2}$ \\
\hline \multirow[t]{3}{*}{$\mathrm{CH}$ (not coord.) } & $0.57^{2,4}$ & $2.7^{2}$ & & $1.28^{2,4}$ & $2.1^{2}$ & \\
\hline & & $0.35^{2}$ & & $-0.32^{2,4}$ & $1.8^{2}$ & \\
\hline & & $-2.7^{2,4}$ & & & & \\
\hline \multirow[t]{5}{*}{ CH (Subst. Ph) } & $10.0^{2,4}$ & $7.9^{5}$ & $11.5^{2}$ & $10.8^{2,4}$ & $10.8^{2}$ & \\
\hline & $6.4^{2,4}$ & & $7.3^{2,4}$ & $8.3^{2,4}$ & $7.0^{2}$ & \\
\hline & $1.5\left(+\mathrm{H}_{2} \mathrm{O}\right)^{4}$ & & $5.4^{2}$ & $8.0-7.5^{5}$ & $4.8^{2}$ & \\
\hline & & & & $7.2^{2,4}$ & & \\
\hline & & & & $3.9^{2,4}$ & & \\
\hline \multirow[t]{2}{*}{$\mathrm{NH}_{2}$} & $1.3^{2}$ & & $-12.0^{2}$ & & & \\
\hline & $1.1^{2,4}$ & & & & & \\
\hline $\mathrm{NH}$ & & $-8.7^{2,4}$ & & $-2.86^{2,4}$ & & \\
\hline $\mathrm{OH}\left(\mathrm{H}_{2} \mathrm{O}\right)$ & & & & $2.1^{6}$ & & \\
\hline
\end{tabular}

${ }^{1}$ Data in $\mathrm{CD}_{2} \mathrm{Cl}_{2} ;{ }^{2}$ Singlet; ${ }^{3}$ Very broad; ${ }^{4}$ Broad; ${ }^{5}$ Multiplet; ${ }^{6}$ Obscured; ${ }^{7}$ Ref. 40. 


\section{Journal Name}

\section{ARTICLE}

a)

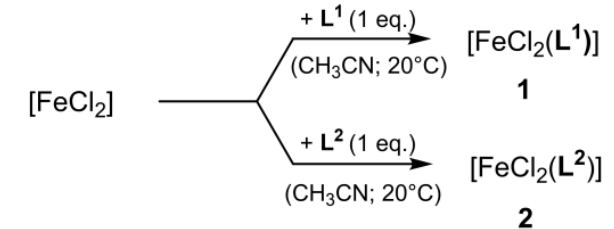

b)

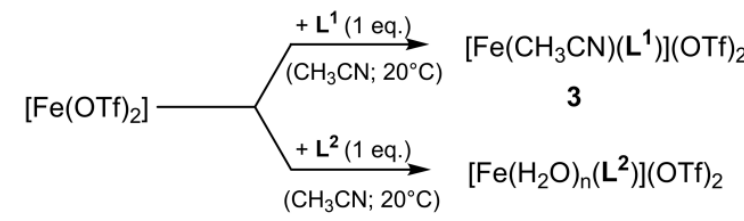

Scheme 1. Syntheses of the complexes reported in this study.

\section{Characterization and studies of complexes 1-4}

In most of the complexes obtained by reaction of iron(II) salts $\left(\mathrm{Cl}^{-}\right.$or $\left.\mathrm{SO}_{3} \mathrm{CF}_{3}{ }^{-}\right)$with TPA derivatives, the metal centre adopts a distorted octahedral geometry, where the tripod coordinated in the $\kappa^{4}$ mode. ${ }^{40,44,47,48,58,64-69}$ In contrast, only a few number of complexes display a distorted trigonal-bipyramidal geometry, ${ }^{40,41,44,48,49}$ and moreover much less examples, where the metal is in a square-pyramidal environment, are known. ${ }^{42,43,46}$

\section{Characterization of " $\mathrm{FeCl}_{2}$ " complexes 1 and 2}

$\left[\mathrm{FeCl}_{2}\left(\mathrm{~L}^{1}\right)\right]$ (1). We have not been able to isolate crystals suitable for an X-ray diffraction analysis, therefore the structure of 1 , shown in Chart 2, is based on spectroscopic data only. The structure of $\mathbf{1}$ was proposed by comparing its ${ }^{1} \mathrm{H}$ NMR pattern (see Table 2) with that of the already known complex $\left[\mathrm{FeCl}_{2}\left(\mathbf{L}^{\mathrm{a}}\right)\right]\left(\mathbf{L}^{\mathrm{a}}=\mathrm{Ph}_{2} \mathrm{TPA}\right)$ (see Chart 1 for ligand structure), for which the molecular structure has been well established by crystallography. ${ }^{40}$ The main features in this structure are the tridentate coordination mode of the ligand $\mathbf{L}^{\mathbf{1}}$, with one substituted pyridine remaining out of the coordination sphere, and the pentacoordination of the iron atom which lies in a distorted trigonal-bipyramidal environment. The ${ }^{1} \mathrm{H}$ NMR spectrum of 1 reflects a high-spin state for the metal with broad signals. For example, a very broad signal, attributable to the $\alpha$ proton of a coordinated pyridine, appears at $119.2 \mathrm{ppm}$. Three signals corresponding to the two protons each are observed at $\delta=86.1,32.2$ and 17.3 ppm, that are assigned to the methylene groups (Table 2). Two other sharp resonances and two broad signals are found at 53.8 and 21.2, and 7.3 and 3.9 ppm. They may correspond to

the $\beta, \beta^{\prime}$ and $\gamma$ protons of the coordinated pyridine, by analogy with similar Fe-TPA complexes ${ }^{40}$

Chart 2. Proposed structure of complex 1.

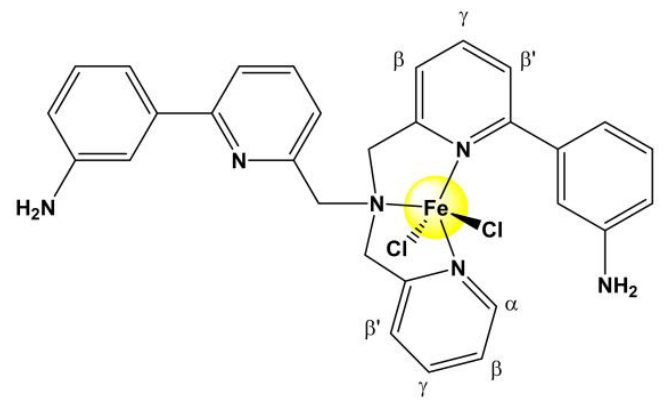

The diamagnetic region of the spectrum displays on the one hand three broad peaks at 10.0,6.4, and 1.5 (with water) ppm that are assigned to eight protons of two phenyl substituents, and on the other hand two singlets at 1.3 , and $1.1 \mathrm{ppm}$ that are attributed to two amine $\left(\mathrm{NH}_{2}\right)$ groups. It remains in the diamagnetic region one broad resonance at $0.57 \mathrm{ppm}$, corresponding to three protons, which are due to the uncoordinated pyridine. The formulation of $\mathbf{1}$ was conforted by the ESI-MS spectrum, where the molecular peak was detected at 677.10 (calculated: 677.12). UV-Visible spectroscopy of the complex in acetonitrile displayed two main absorption bands in the 250-300 $\mathrm{nm}$ wavelength range, and a less intense absorption band at $324 \mathrm{~nm}$ (Table 3). These three bands are consistent with previous results obtained with analogous TPA complexes, such as $\left[\mathrm{FeCl}_{2}\left(\mathrm{~L}^{\mathrm{a}}\right)\right]{ }^{40}$ It should be noted that the use of a TPA ligand having two pyridyl groups substituted each by a phenylamine moiety, does not modify the mode of coordination of such a ligand towards a " $\mathrm{FeCl}_{2}$ " core, compared to that observed with the $\mathrm{Ph}_{2}$-TPA ligand. ${ }^{40}$

[ $\left.\mathrm{FeCl}_{2}\left(\mathrm{~L}^{2}\right)\right]$ (2). Reaction of $\mathrm{FeCl}_{2}$ with a macrocyclic ligand, namely $\mathbf{L}^{2}$ (see Chart 1 ) containing two different coordination sites for $\mathrm{Fe}^{2+}$, has given in good yield a yellow-brown solid $\mathbf{2}$. The analytical data of this solid indicate that $\mathbf{2}$ was formed with 1.5 molecules of water, and therefore was formulated as $\left[\mathrm{FeCl}_{2}\left(\mathrm{~L}^{2}\right)\right]$. $1.5 \mathrm{H}_{2} \mathrm{O}$. This formulation was confirmed by X-ray diffraction of a single crystal (see ORTEP in Fig. 1), obtained at room temperature by slow diffusion of diethyl ether in a dichloromethane solution of $\mathbf{2}$ with, however, the loss of $\mathrm{H}_{2} \mathrm{O}$. Selected bond lengths and angles for $\mathbf{2}$ are given in the caption of Fig. 1. The structural analysis of $\mathbf{2}$ reveals (i) the tridentate coordination mode of the ligand via its TPA arm, with one substituted pyridine remaining out of the coordination sphere that is completed by two chlorides and (ii) a distorted 
pentagonal geometry, for which the Addison index is equal to $\tau=0.39$, i.e. a value indicative of a noticeable distortion with respect to either the ideal trigonal-bipyramidal environment ( $\tau$ $=1$ ) or the square-pyramidal one $(\tau=0) .^{70}$

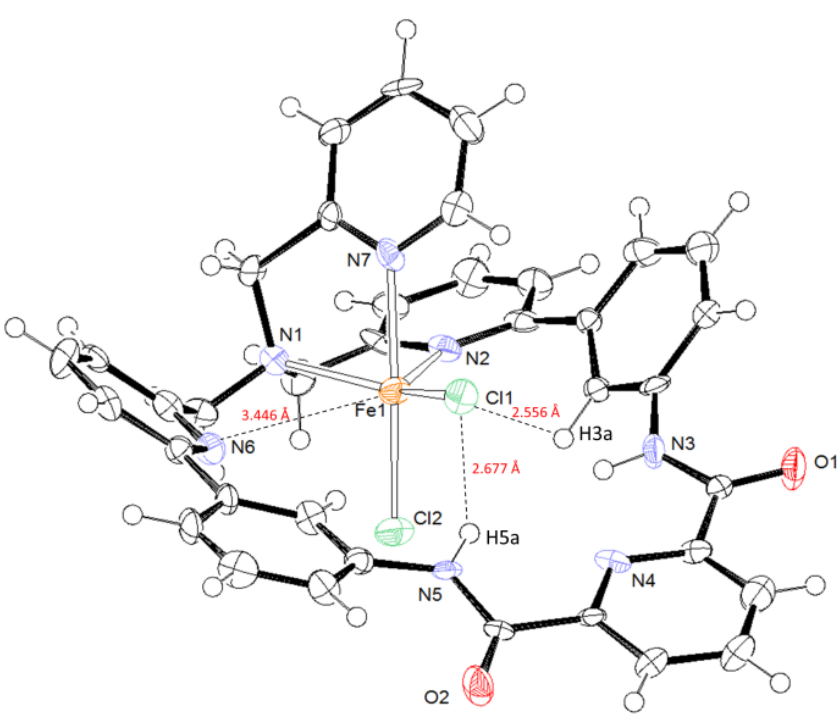

Fig. 1. ORTEP diagram of $\left[\mathrm{FeCl}_{2}\left(\mathrm{~L}^{2}\right)\right](\mathbf{2})$. Here and elsewhere non-hydrogen atoms are shown with $50 \%$ ellipsoids. Selected bond distances $(\AA \AA)$ and angles $\left({ }^{\circ}\right)$ : N1 $\mathrm{Fe} 1=2.240(7), \mathrm{N} 2-\mathrm{Fe} 1=2.299(8), \mathrm{N} 7-\mathrm{Fe} 1=2.154(8), \mathrm{Fe} 1-\mathrm{Cl} 1=2.308(3), \mathrm{Fe} 1-\mathrm{Cl} 2=2.366(3)$, N7-Fe1-N1=77.5(3), N7-Fe1-N2=76.9(3), N1-Fe1-N2=78.2(3), N7-Fe1-Cl2=167.9(2), N1 $\mathrm{Fe} 1-\mathrm{Cl} 2=94.5(2), \mathrm{N} 2-\mathrm{Fe} 1-\mathrm{Cl} 2=92.8(2), \mathrm{N} 7-\mathrm{Fe} 1-\mathrm{Cl} 1=90.1(2), \mathrm{N} 1-\mathrm{Fe} 1-\mathrm{Cl} 1=144.70(19), \mathrm{N} 2$ $\mathrm{Fe} 1-\mathrm{Cl} 1=131.4(2), \mathrm{Cl} 2-\mathrm{Fe} 1-\mathrm{Cl} 1=101.54(10)$.

The small angles N7-Fe1-N1 $\left(77.5(3)^{\circ}\right)$ and N7-Fe1-N2 $\left(76.9(3)^{\circ}\right)$ reflect the high distortion observed in this geometry that is, however closer to a square-pyramid than a trigonalpyramid. The Fe"-N distances, ranging from $2.130(2)$ to 2.259(2) $\AA$, and $\mathrm{Fe}-\mathrm{Cl}$ ( $\square 2.323 \AA$ ) are consistent with a high spin for the metal centre in 2 (see Fig. 1, caption). ${ }^{43}$ As shown in Fig. 1, the long $\mathrm{Cl} 1-\mathrm{H}$ distances, e.g. $\mathrm{Cl} 1-\mathrm{HN} 3$ and $\mathrm{Cl} 1-\mathrm{HN} 5$, suggest at the utmost very weak interactions between these atoms. This indicates that the macrocyclic ligand $\mathbf{L}^{2}$ has a large cavity, which can explain why the PydCA (pyridinedicarboxamide) arm does not coordinate to the " $\mathrm{FeCl}_{2}$ " core in 2. The molecular conductivity measurement of a $1.5 \mathrm{mM}$ solution of 2 in acetonitrile yielded $\Lambda=24 \mathrm{~S} \mathrm{~cm}^{2} \mathrm{~mol}^{-1}$, indicating a neutral electrolytic behaviour of the compound in solution at this concentration, ${ }^{71-72}$ this implies that solvent $\left(\mathrm{CH}_{3} \mathrm{CN}\right)$ has not displaced any chloride ligand from the coordination sphere. The ${ }^{1} \mathrm{H}$ NMR spectrum of 2 in $\mathrm{CD}_{3} \mathrm{CN}$ exhibits numerous well-defined paramagnetically shifted signals over the 103 to $53 \mathrm{ppm}$ range, which confirms the highspin state of the iron atom in the complex (see Table 2). All these data converge towards retention of the solid state structure when the compounds are dissolved in $\mathrm{CH}_{3} \mathrm{CN}$ or $\mathrm{CD}_{3} \mathrm{CN}$.

Voltammetric studies of complex 2 were carried out under inert atmosphere in dichloromethane (DCM) and acetonitrile ( $\mathrm{MeCN}$ ) with $\mathrm{NBu}_{4} \mathrm{PF}_{6}$ as supporting electrolyte. In $\mathrm{DCM}$, the complex 2 displayed an irreversible oxidation peak by cyclic voltammetry (CV) at $E_{\mathrm{pa}}(1)=0.33 \mathrm{~V}$ vs Fc at $v=0.1 \mathrm{~V} / \mathrm{s}$ (Fig. 2) when scanning toward positive potential values.
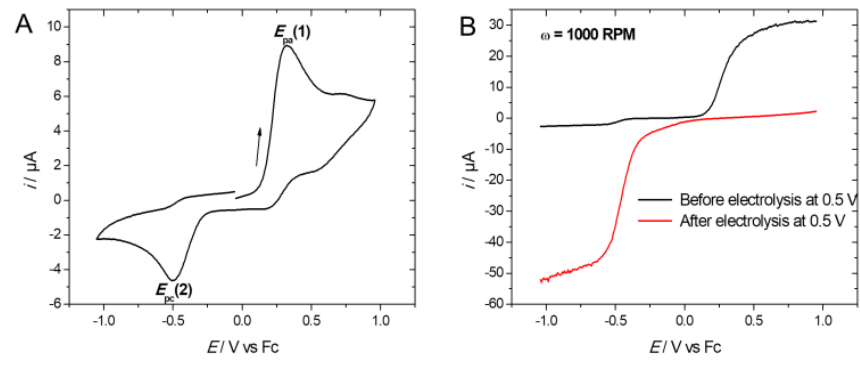

Fig. 2. A) $\mathrm{CV}\left(E / \mathrm{V}\right.$ v Fc) at a Pt working electrode of $2(1 \mathrm{mM})$ in $\mathrm{CH}_{2} \mathrm{Cl}_{2} / \mathrm{NBu}_{4} \mathrm{PF}_{6} 0.1$ $\mathrm{M}(\mathrm{v}=0.1 \mathrm{v} / \mathrm{s}) ; \mathrm{B}) \mathrm{RDEV}$ before (black) and after (red) exhaustive electrolysis at $0.5 \mathrm{~V}$ vs Fc $(\omega=1000$ RPM $)$.

On the back scan, a reduction peak was detected at $E_{\mathrm{pc}}(2)=-$ $0.50 \mathrm{~V}$. This latter peak was not present when the scan was processed in negative direction. Variation of the scan rate did not modify the redox behavior. Rotating-disk Electrode Voltammetry (RDEV) showed an oxidation wave at $E_{1 / 2}=0.30 \mathrm{~V}$ vs Fc (Fig. 2). Exhaustive electrolysis of the solution at $0.5 \mathrm{~V}$ suggested a monoelectronic oxidation process from coulometric measurements. RDEV after electrolysis displayed a unique reduction wave at $-0.50 \mathrm{~V}$. Reduction of the electrochemically generated species yielded back the initial complex 2. In acetonitrile, the same behaviour was observed, except a slight difference in redox potential values which can be ascribed to the higher polarity of the medium.

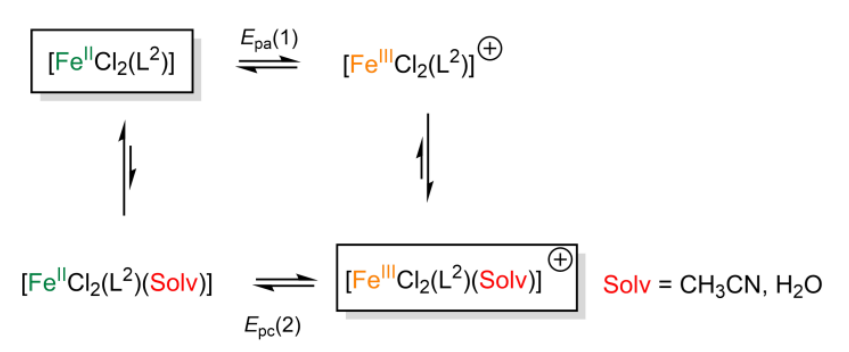

Scheme 2. Square scheme proposed for the redox behaviour of complex $\mathbf{2}$

Table 4. Electrochemical data ( $E / \mathrm{V}$ vs Fc, $v=0.1 \mathrm{~V} / \mathrm{s}$ ) for complex 2 in $\mathrm{CH}_{3} \mathrm{CN}$ compared to those obtained for complex $\left[\mathrm{FeCl}_{2}\left(\mathrm{~L}^{\mathrm{a}}\right)\right]$, [ $\left.\mathrm{FeCl}_{2}(\mathrm{TPA})\right], \quad\left[\mathrm{FeCl}_{2}\left(\mathrm{Me}_{1} \mathrm{TPA}\right)\right]$, $\left[\mathrm{FeCl}_{2}\left(\mathrm{Me}_{2} \mathrm{TPA}\right)\right], \quad\left[\mathrm{FeCl}_{2}\left(\mathrm{Me}_{3} \mathrm{TPA}\right)\right], \quad\left[\mathrm{FeCl}_{2}\left({ }^{\mathrm{OMe} 2} \mathrm{PhTPA}\right)\right], \quad\left[\mathrm{FeCl}_{2}\left({ }^{\mathrm{OMe} 2} \mathrm{Ph}_{2} \mathrm{TPA}\right)\right]$ and $\left[\mathrm{FeCl}_{2}\left({ }^{\mathrm{OMe} 2} \mathrm{Ph}_{3} \mathrm{TPA}\right)\right]$.

\begin{tabular}{lll}
\hline Complex & $E_{\mathrm{pa}}$ & $E_{\mathrm{pc}}$ \\
\hline $\mathbf{2}$ & $0.26^{\mathrm{a}}$ & $-0.38^{\mathrm{a}}$ \\
{$\left[\mathrm{FeCl}_{2}\left(\mathrm{~L}^{\mathrm{a}}\right)\right]^{\mathrm{b}}$} & 0.13 & -0.39 \\
{$\left[\mathrm{FeCl}_{2}(\mathrm{TPA})\right]^{\mathrm{b}}$} & -0.15 & -0.23 \\
{$\left[\mathrm{FeCl}_{2}\left(\mathrm{Me}_{1} \mathrm{TPA}\right)\right]^{\mathrm{b}}$} & -0.10 & -0.19 \\
{$\left[\mathrm{FeCl}_{2}\left(\mathrm{Me}_{2} \mathrm{TPA}\right)\right]^{\mathrm{b}}$} & 0.03 & -0.08 \\
{$\left[\mathrm{FeCl}_{2}\left(\mathrm{Me}_{3} \mathrm{TPA}\right)\right]^{\mathrm{b}}$} & 0.16 & 0.03 \\
{$\left[\mathrm{FeCl}_{2}\left({ }^{\mathrm{OMe} 2} \mathrm{PhTPA}\right)\right]^{\mathrm{c}}$} & -0.15 & -0.24 \\
{$\left[\mathrm{FeCl}_{2}\left({ }^{\mathrm{OMe} 2} \mathrm{Ph}_{2} \mathrm{TPA}\right)\right]^{\mathrm{c}}$} & -0.33 & -0.41 \\
{$\left[\mathrm{FeCl}_{2}\left({ }^{\mathrm{OMe} 2} \mathrm{Ph}_{3} \mathrm{TPA}\right)\right]^{\mathrm{c}}$} & 0.00 & -0.08 \\
\hline
\end{tabular}

${ }^{\mathrm{a}}$ Irreversible peak; ${ }^{\mathrm{b}}$ Ref.44; ${ }^{\mathrm{c}}$ Ref.46. 
Hence, these results suggest that the monoelectronic oxidation of the complex 2 at $E_{\mathrm{pa}}(1)$ is followed by a chemical reaction, leading to a new species which can be reduced at $E_{\mathrm{pc}}(2)$. The large peak-to-peak separation $(800 \mathrm{mV}$ ) indicates a strong rearrangement of the coordination sphere upon electron exchange. This can be considered in the frame of a square-scheme mechanism, as often found for coordination metal complexes. ${ }^{73}$ Here, the oxidation of $\mathbf{2}$ leads probably to the formation of a transient pentacoordinated $\left[\mathrm{Fe}^{\mathrm{III}} \mathrm{Cl}_{2}\left(\mathrm{~L}^{2}\right)\right]^{+}$ species, which evolves toward a more stable hexacoordinated complex $\left[\mathrm{Fe}^{\prime \prime \prime} \mathrm{Cl}_{2}\left(\mathrm{~L}^{5}\right)(\mathrm{Solv})\right]^{+}$by incorporation of solvent in the coordination sphere (Solv $=\mathrm{H}_{2} \mathrm{O}, \mathrm{CH}_{3} \mathrm{CN}$ ) (Scheme 2). The binding of a pyridyl moiety to the iron(III) centre is unlikely due to the rigidity of the ligand.

A contrario, the reduction of this species yields back the initial complex $\mathbf{2}$ by solvent release. For comparison with similar complexes, electrochemical data in acetonitrile are gathered in Table 4. Noticeably, the oxidation potential of complex 2 (0.26 $\mathrm{V}$ vs $\mathrm{Fc}$ ) in acetonitrile is significantly much higher than that reported for analogous complexes. If one assumes that the metal ion is penta-coordinated including two chloride ions, this high potential value can be ascribed to the ligand topology which disfavours the stabilization of the metal ion in a high redox state (here $\mathrm{Fe}^{\text {III) }}$ ) by the electrolyte. Such an effect was previously observed for analogous copper complexes. ${ }^{74,75}$

Table 3. UV-Vis Spectroscopic data $\left(\lambda_{\max }(\mathrm{nm})\left[\varepsilon_{\max }\left(\mathrm{M}^{-1} \cdot \mathrm{cm}^{-1}\right)\right]\right)$ for $1,2,3$ and $\mathbf{4}$ and analogous complexes in $\mathrm{CH}_{3} \mathrm{CN}$ at room temperature.

\begin{tabular}{|c|c|c|c|c|}
\hline Complex & $\lambda_{\max }(\mathrm{nm})\left[\varepsilon_{\max }\left(\mathrm{M}^{-1} \mathrm{~cm}^{-1}\right)\right]$ & & $\Lambda / \mathrm{S} \mathrm{cm}^{2} \mathrm{~mol}^{-1}$ & Ref. \\
\hline 1 & 257 [18550], 285 [14500] & $324[8160]$ & - & This work \\
\hline 2 & $253[10500]$ & $341[3280], 386$ [1785] & 24 & This work \\
\hline 3 & 259 [16300], 283 [13360] & $335[4880]$ & - & This work \\
\hline 4 & 253 [18100], 284 [18600] & - & 138 & This work \\
\hline$\left[\mathrm{FeCl}_{2}(\mathrm{TPA})\right]$ & $256[8350]$ & 427 [1440] & 30 & \\
\hline$\left[\mathrm{FeCl}_{2}\left(\mathrm{~L}^{\mathrm{a}}\right)\right]$ & 246 [17900], 283 [17030] & $387[6500]$ & 28 & 40 \\
\hline$\left[\mathrm{FeCl}_{2}(\mathrm{MeTPA})\right]$ & $258[8860]$ & $411[1320]$ & 36 & 44 \\
\hline$\left[\mathrm{FeCl}_{2}\left(\mathrm{Me}_{2} \mathrm{TPA}\right)\right]$ & $261[8770]$ & $390[900]$ & 49 & 44 \\
\hline$\left[\mathrm{FeCl}_{2}\left(\mathrm{Me}_{3} \mathrm{TPA}\right)\right]$ & $265[6090]$ & $371[460]$ & 42 & 44 \\
\hline$\left[\mathrm{FeCl}_{2}\left(\mathrm{Br}_{1} \mathrm{TPA}\right)\right]$ & $261[7520]$ & 403.5 [1030] & 30 & 40 \\
\hline$\left[\mathrm{FeCl}_{2}\left(\mathbf{L}^{\mathbf{b}}\right)\right]$ & $262.5[\mathrm{sh}], 269$ [10430] & $373[620]$ & 32 & 40 \\
\hline$[\mathrm{Fe}(\mathrm{FTPA})]$ & - & $415[1500]$ & 31 & 45 \\
\hline$\left[\mathrm{FeCl}_{2}\left(\mathrm{~F}_{2} \mathrm{TPA}\right)\right]$ & - & $390[1400]$ & 36 & 45 \\
\hline$\left[\mathrm{FeCl}_{2}\left(\mathrm{~F}_{3} \mathrm{TPA}\right)\right]$ & $261[8050]$ & - & 41 & 41 \\
\hline$\left[\mathrm{FeCl}_{2}(\mathrm{CITPA})\right]$ & $259[8300]$ & $392[1200]$ & - & 49 \\
\hline$\left[\mathrm{FeCl}_{2}\left(\mathrm{Cl}_{2} \mathrm{TPA}\right)\right]$ & $267[9400]$ & $373[600]$ & - & 49 \\
\hline$\left[\mathrm{FeCl}_{2}\left(\mathrm{Cl}_{3} \mathrm{TPA}\right)\right]$ & $269[13300]$ & - & - & 49 \\
\hline$\left[\mathrm{FeL}_{2}(\mathrm{ClTPA})\right](\mathrm{OTf})_{2}{ }^{\mathrm{a}}$ & $258[10200]$ & 354 [1300] & - & 49 \\
\hline$\left[\mathrm{FeL}_{2}\left(\mathrm{Cl}_{2} \mathrm{TPA}\right)\right](\mathrm{OTf})_{2}{ }^{\mathrm{a}}$ & 264 [8500] & $351[600]$ & - & 49 \\
\hline$\left[\mathrm{FeL}_{2}\left(\mathrm{Cl}_{3} \mathrm{TPA}\right)\right](\mathrm{OTf})_{2}{ }^{\mathrm{a}}$ & $268[9400]$ & $344[600]$ & - & 49 \\
\hline$\left[\mathrm{FeCl}_{2}\left({ }^{\mathrm{OMe} 2} \mathrm{PhTPA}\right)\right]$ & 258 [12326], 280 [8268] & $376[1015]$ & 46 & 46 \\
\hline$\left[\mathrm{FeCl}_{2}\left({ }^{\mathrm{OMe} 2} \mathrm{Ph}_{2} \mathrm{TPA}\right)\right]$ & $251[\mathrm{sh}], 284$ [14735] & $368[752]$ & 47 & 46 \\
\hline$\left[\mathrm{FeCl}_{2}\left({ }^{\mathrm{OMe} 2} \mathrm{Ph}_{3} \mathrm{TPA}\right)\right]$ & 247 [sh], 278 [19003] & - & 23 & 46 \\
\hline$\left[\mathrm{FeCl}_{2}(\mathrm{PivTPA})\right]$ & - & $419[840]$ & 11 & 47 \\
\hline$\left[\mathrm{FeCl}_{2}\left(\mathrm{Piv}_{2} \mathrm{TPA}\right)\right]$ & - & $379[960]$ & 6 & 47 \\
\hline$\left[\mathrm{FeCl}_{2}\left(\mathrm{RCO}_{2} \mathrm{TPA}\right)\right]$ & - & $400[740]$ & 20 & 47 \\
\hline$\left[\mathrm{FeCl}_{2}(\right.$ ITPA) $]$ & $258[5500]$ & $375[1000]$ & 19 & 48 \\
\hline$\left[\mathrm{FeCl}_{2}\left(\mathrm{I}_{2} \mathrm{TPA}\right)\right]$ & $246[7100]$ & $370[500]$ & 23 & 48 \\
\hline$\left[\mathrm{FeCl}_{2}\left(\mathrm{I}_{3} \mathrm{TPA}\right)\right]$ & - & - & 15 & 48 \\
\hline$\left[\mathrm{FeCl}_{2}\left(\alpha-\mathrm{CN}_{2} \mathrm{TPA}\right)\right]$ & - & $462[800]$ & 21 & 69 \\
\hline$\left[\mathrm{FeCl}_{2}\left(\alpha-\mathrm{CONH}_{2} \mathrm{TPA}\right)\right]$ & - & 368 [1300], 505 [1660] & - & 69 \\
\hline
\end{tabular}

${ }^{\mathrm{a}} \mathrm{L}=\mathrm{CH}_{3} \mathrm{CN}$

\section{Characterization of "Fe(OTf), complexes 3 and 4}

$\left[\mathrm{Fe}\left(\mathrm{CH}_{3} \mathrm{CN}\right)\left(\mathrm{L}^{1}\right)\right](\mathrm{OTf})_{2}$ (3). Reaction of $\left(\mathrm{Fe}(\mathrm{OTf})_{2}\right.$ with $\mathrm{L}^{\mathbf{1}}$ in $\mathrm{CH}_{3} \mathrm{CN}$ gave a red-orange solid 3 , in valuable yield (Scheme $1 b)$. Formulation of $\mathbf{3}$ is based on $\mathrm{X}$-ray analysis of a single crystal of the complex obtained by slow diffusion of $\mathrm{Et}_{2} \mathrm{O}$ into a $\mathrm{CH}_{3} \mathrm{CN}$ solution of the product in a sealed tube. The molecular structure of $\mathbf{3}$ (see Fig. 3) shows that the complex is an ionic species, with a pentagonal dication in which the tripodal ligand $\left(\mathrm{PhNH}_{2}\right)_{2}$ TPA coordinates in the tetradentate fashion, the coordination sphere being completed by a $\mathrm{CH}_{3} \mathrm{CN}$ molecule. Two triflate anions ensure the neutrality of the compound. The main features in this structure are (i) the metal centre lying in a distorted pentagonal environment and (ii) an Addison index of 0.5 , indicating that the geometry is equally distant between 
a square-pyramid and a trigonal-pyramid. The acute angles N5Fe-N1, N6-Fe-N1, and N2-Fe-N1 $\left(\square 75.86(6)^{\circ}\right)$ confirm the high distortion observed in this geometry (Fig. 3 caption). In $\mathbf{3}$, all the Fe"-N distances, ranging from 2.116(2) to 2.215 (2) $\AA$, are typical of a high spin for the metal centre. Therefore, the crystallographic data clearly indicate that the two triflate ligands in $\mathrm{Fe}(\mathrm{OTf})_{2}$ are both displaced from the coordination sphere of the metal when this complex reacted with the disubstituted-TPA $\mathbf{L}^{1}$ ligand in a good coordinating solvent, such as $\mathrm{CH}_{3} \mathrm{CN}$. It should be noted that in the cation of $\mathbf{3}$, the nitrogen atoms of the two $\mathrm{NH}_{2} \mathrm{Ph}$-substituted pyridine groups of the tertiary amine are bound to the iron centre, which notably differs from what was observed in an analogous neutral compound previously obtained by treating $\mathrm{FeCl}_{2}$ with $\mathrm{Ph}_{2}$-TPA in which one of the substituted pyridine is not bound to the metal. ${ }^{40}$ Obviously, $\left[\mathrm{Fe}\left(\mathrm{CH}_{3} \mathrm{CN}\right)\left(\mathrm{L}^{\mathbf{1}}\right)\right](\mathrm{OTf})_{2}$ (3) can be compared to the already known six-coordinate complex $\left[\mathrm{Fe}\left(\mathrm{CH}_{3} \mathrm{CN}\right)_{2}(\mathrm{TPA})\right](\mathrm{OTf})_{2}{ }^{64}$ both were obtained in very similar conditions. Both ligands, $\mathbf{L}^{1}$ and TPA, act as tetradentates in $\mathbf{3}$ as well as in the bis-nitrile derivative. But, in the latter, the metal centre lies in a nearly standard octahedral "N6" environment with Fe-N distances of 1.934(3)-1.978(3) $\AA$, ${ }^{64}$ which are typical of low-spin iron(II), ${ }^{76}$, whereas in $\mathbf{3}$, the iron atom lies in a distorted pentagonal "N5" geometry with characteristic Fe-N distances of a high-spin Fe(II) (see above). Another obvious difference in these structures lies in the values of the Fe-N-C $\left(\mathrm{CH}_{3}\right)$ angles, which are nearly linear in the bis-nitrile compound $\left(175^{\circ}\right){ }^{64}$ whereas the distortion from linearity becomes more marked in $3\left(171.11(19)^{\circ}\right)$. These differences are probably due to steric factors, which are more pronounced in $\mathbf{3}$ than in the bis-nitrile complex. The ${ }^{19} \mathrm{~F}$ NMR spectrum of $\mathbf{3}$ in $\mathrm{CD}_{3} \mathrm{CN}$ solution exhibits only one resonance at $\delta=-78.2 \mathrm{ppm}$ (see Experimental section), in line with the presence of free triflate ions, ${ }^{77}$ indicating that the structure of the complex as seen in the solid state is retained in solution. The ${ }^{1} \mathrm{H}$ NMR spectrum displays some paramagnetically shifted and broad resonances within the $120-20 \mathrm{ppm}$ range, thus confirming the high-spin state of the metal as deduced from the crystal structure analysis of the solid. The ${ }^{1} \mathrm{H}$ NMR pattern of $\mathbf{3}$ presents some similarities and also some differences with those of other distorted (albeit more or less distorted) trigonal-bipyramidal derivatives, such as complexes $\mathbf{1}, \mathbf{2}$, $\left[\mathrm{FeCl}_{2}\left(\mathbf{L}^{\mathrm{a}}\right)\right]$ and $\left[\mathrm{FeCl}_{2}\left(\mathbf{L}^{\mathbf{b}}\right)\right]$ (see Table 2 ). Differences between the patterns of these five complexes are due mainly to TPA ligands that have varied pyridine substituents, and as a result different distortion degrees of these geometries relative to the ideal trigonal-bipyramid. In spite of some differences, the ${ }^{1} \mathrm{H}$ NMR resonances of $\mathbf{3}$ have been attributed as indicated in Table 2 by comparison with those of the distorted pentagonal complexes 1, 2, $\left[\mathrm{FeCl}_{2}\left(\mathbf{L}^{\mathbf{a}}\right)\right]$ and $\left[\mathrm{FeCl}_{2}\left(\mathrm{~L}^{\mathbf{b}}\right)\right]$.

$\left[\mathrm{Fe}\left(\mathrm{H}_{2} \mathrm{O}\right)_{n}\left(\mathrm{~L}^{2}\right)\right](\mathrm{OTf})_{2}(\mathbf{4})(\mathrm{n}=\mathbf{1}$ or 2$)$. Complex 4 was obtained in moderate yield, as a red-orange solid by reacting $\mathrm{Fe}(\mathrm{OTf})_{2}$ with the macrocyclic ligand $\mathbf{L}^{\mathbf{2}}$. Unfortunately, we have not been able to isolate crystals of this product suitable for an X-Ray diffraction analysis. Therefore, the structure of $\mathbf{4}$ is based on mass, molar conductance and spectroscopic data. The higher peak observed in the mass spectrum at $\mathrm{m} / \mathrm{z}=880.2$, corresponding to $\left\{\mathrm{Fe}(\mathrm{OTf})\left(\mathrm{H}_{2} \mathrm{O}\right)_{4}\left(\mathrm{~L}^{2}\right)\right\}^{+}$, can be explained by the presence of traces of water in the solvent $\left(\mathrm{CH}_{3} \mathrm{CN}\right)$. The presence of $\mathrm{H}_{2} \mathrm{O}$ in 4 is confirmed by resonance at $2.1 \mathrm{ppm}$ in the ${ }^{1} \mathrm{H}$ NMR spectrum (Table 2). The molar conductivity, $\Lambda=$ $138 \mathrm{~S} \mathrm{~cm}^{2} \mathrm{~mol}^{-1}$ was measured in $\mathrm{CH}_{3} \mathrm{CN}$ and its value indicates an ionic behaviour in solution. No resonance attributable to a coordinated triflate was observed in the ${ }^{19} \mathrm{~F} \mathrm{NMR}\left(\mathrm{CD}_{3} \mathrm{CN}\right)$ spectrum, and only one species was present. The chemical shift, $\delta=-79.6 \mathrm{ppm}$, corresponds to free triflate ions. This datum suggests for $\mathbf{4}$ a dicationic species in spite of the relatively low value of the molar conductance (see above), which is more characteristic of a singly-charged species than a doubly one. ${ }^{40,65}$ Nevertheless, on the basis of these data, we suggest for 4 either the pentagonal $\left[\mathrm{Fe}\left(\mathrm{H}_{2} \mathrm{O}\right)\left(\mathrm{L}^{2}\right)(\mathrm{OTf})_{2}, 3 \mathrm{H}_{2} \mathrm{O}\right.$ geometry or the octahedral $\left[\mathrm{Fe}\left(\mathrm{H}_{2} \mathrm{O}\right)_{2}\left(\mathrm{~L}^{2}\right](\mathrm{OTf})_{2}, 2 \mathrm{H}_{2} \mathrm{O}\right.$ one. Unhappily, ${ }^{1} \mathrm{H}$ NMR (Table 2) and UV-Visible (Table 3 ) spectroscopies do not allow to distinguish unquestionably between these two possibilities.

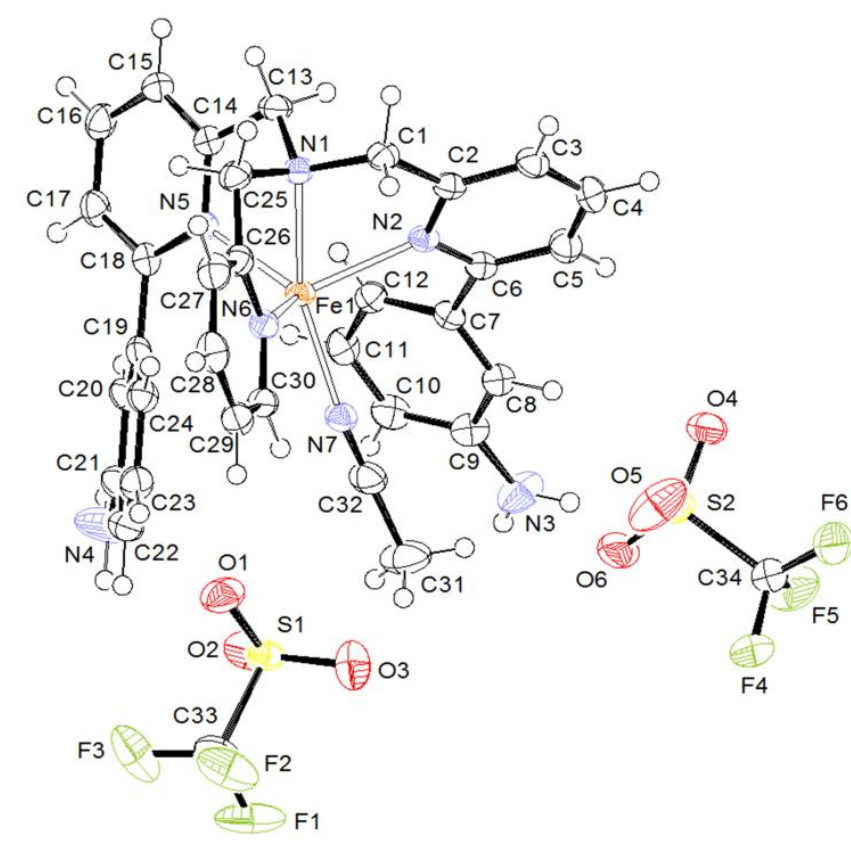

Fig. 3. ORTEP diagram of $\left[\mathrm{Fe}\left(\mathrm{CH}_{3} \mathrm{CN}\right)\left(\mathrm{L}^{1}\right)\right](\mathrm{OTf})_{2}$ (3). Selected bond distances $(\AA ̊)$ and angles $\quad\left({ }^{\circ}\right)$ : $\quad \mathrm{N} 1-\mathrm{Fe} 1=2.2147(17), \quad \mathrm{N} 2-\mathrm{Fe} 1=2.1819(18), \quad \mathrm{N} 5-\mathrm{Fe} 1=2.126(18), \quad \mathrm{N} 6-$ $\mathrm{Fe} 1=2.1555(18), \mathrm{N} 7-\mathrm{Fe} 1=2.1159(19), \mathrm{N} 7-\mathrm{Fe} 1-\mathrm{N} 5=126.54(7), \mathrm{N} 7-\mathrm{Fe} 1-\mathrm{N} 6=93.04(7)$, N5Fe1-N6=111.77(7), N7-Fe1-N2=93.55, N5-Fe1-N2=111.66(7), N6-Fe1-N2=119.17(6), N7$\mathrm{Fe} 1-\mathrm{N} 1=156.83(7), \quad \mathrm{N} 5-\mathrm{Fe} 1-\mathrm{N} 1=76.63(7), \quad \mathrm{N} 6-\mathrm{Fe} 1-\mathrm{N} 1=76.07(6), \mathrm{N} 2-\mathrm{Fe} 1-\mathrm{N} 1=74.89(6)$, C32-N7-Fe1=171.11(19).

\section{Reactivity of complexes 1-4 towards $\mathrm{H}_{2} \mathrm{O}_{2}$}

The reactivity of iron complexes towards $\mathrm{H}_{2} \mathrm{O}_{2}$ was investigated in acetonitrile at room temperature by using UVVis and EPR spectroscopy to monitor the reaction. Addition of hydroperoxide ( 0.5 to 35 molar eq.) to a solution of complex 1 led to the appearance of two absorption bands at $\lambda_{\max }=360$ $\mathrm{nm}\left(\varepsilon=9780 \mathrm{M}^{-1} \mathrm{~cm}^{-1}\right)$ and $314 \mathrm{~nm}\left(\varepsilon=6670 \mathrm{M}^{-1} \mathrm{~cm}^{-1}\right)$. The presence of an isosbestic point at $\lambda_{\max }=336 \mathrm{~nm}$ for 15 eq. indicated that no secondary reaction occurred (see Supporting Information). The spectrum did not evolve after addition of 35 
molar eq.. Moreover, the EPR spectrum of complex 1 after addition of $\mathrm{H}_{2} \mathrm{O}_{2}$ in excess displayed an intense and broad signal at $\mathrm{g}=4.25$. According to previous results, these spectroscopic data suggest the formation of high-spin mononuclear $\mathrm{Fe}^{\mathrm{III-}} \mathrm{O}_{2}$ adducts or dinuclear ( $\mu$-oxo) bis-iron(III) species. $^{78}$

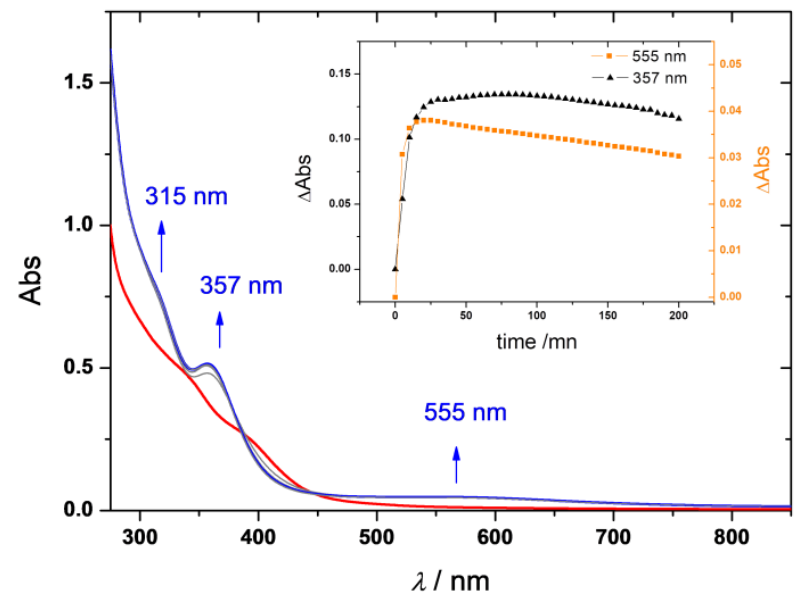

Fig. 4. UV-Vis spectra of $2(1.4 \mathrm{mM})$ in $\mathrm{CH}_{3} \mathrm{CN}$ (red) and after (blue) addition of 35 molar eq. of $\mathrm{H}_{2} \mathrm{O}_{2}$. Inset: monitoring of the absorbance vs time at $\lambda_{\max }=555 \mathrm{~nm}$ (black triangles) and $\lambda_{\max }=357 \mathrm{~nm}$ (orange squares).

Different results were obtained for the macrocyclic complexes 2 and 4 . Hence, the addition of hydrogen peroxide ( 25 eq.) at $293 \mathrm{~K}$ induced the formation of two absorption bands at $\lambda_{\max }=$ $357 \mathrm{~nm}$ and $555 \mathrm{~nm}$ for 2, as well as $362 \mathrm{~nm}$ and $587 \mathrm{~nm}$ for 4 (Fig. 4). In both cases, the monitoring of the absorbance for these two new bands indicated a relatively fast $(20 \mathrm{~min})$ process at room temperature, and a rather slow evolution of the formed species (>2h) (see for example Fig. 4 for complex 2, inset). According to literature's data, these spectroscopic features can be ascribed to either hydroperoxo $\mathrm{Fe}^{\text {III }}(\mathrm{OOH})$ or $\mathrm{Fe}^{\text {III }}(\mathrm{OH})$ hydroxo species. ${ }^{49,69,79,80}$ Indeed, these species classically display a hydroperoxo or hydroxo to $\mathrm{Fe}^{\mathrm{III}}$ charge transfer (LMCT) in the 310-360 and 500-600 nm wavelength ranges ( $\varepsilon=3600-5300$, and $1000-2000 \mathrm{M}^{-1} \mathrm{~cm}^{-1}$, respectively). Also, phenolate Fe"I complexes exhibit absorption bands in this wavelength range. ${ }^{29}$

$$
\begin{aligned}
& \left.\left[\mathrm{FeCl}_{2}\left(\mathrm{~L}^{2}\right)\right]+\mathrm{H}_{2} \mathrm{O}_{2} \stackrel{\mathrm{CH}_{3} \mathrm{CN}}{\longrightarrow}\left[\left\{\mathrm{Fe}^{\prime \prime \prime}(\mu-\mathrm{OH})\left(\mathrm{OL}^{2}\right)\right\}_{2}\right]\left[\mathrm{FeCl}_{3}\right)_{2}(\mu-\mathrm{O})\right], 3 \mathrm{H}_{2} \mathrm{O} \\
& 2 \\
& 2 \text { ' }
\end{aligned}
$$

Scheme 3. Formation of complex $\mathbf{2}^{\prime}$

It should be noted that any tentative to react complex $\mathbf{2}$ with $\mathrm{O}_{2}$ failed, when dioxygen was bubbled through a $\mathrm{CH}_{3} \mathrm{CN}$ solution of $\mathbf{2}$ (under UV-Visible monitoring). Therefore, stronger oxidants than $\mathrm{O}_{2}$ are required for oxidizing this di-iron compound. For this, compound 4 was reacted with 10 eq. of $\mathrm{H}_{2} \mathrm{O}_{2}$ in $\mathrm{CH}_{3} \mathrm{CN}$ (Scheme 3). As mentioned above, after stirring and requested treatments, small amounts of a red-orange powder, 2', was isolated. In order to better understand this process this product has been analysed. The UV-Visible spectrum of 2' in $\mathrm{CH}_{3} \mathrm{CN}$ displays a pattern close to that described for $\mathbf{2}$ (see Fig. 4). Crystals of 2', suitable for an X-ray study have been obtained (see experimental part). Compound 2', that has been isolated in low yields, has been characterized only in the solid state by crystallography. X-ray diffraction analysis (Fig. 5) revealed that the ionic complex $\left[\left\{\mathrm{Fe}\left(\mathrm{OL}^{2^{\prime}}\right)\right\}_{2}(\mu-\right.$ $\left.\mathrm{OH})_{2}\right]^{2+},\left[\left(\mathrm{FeCl}_{3}\right)_{2}(\mu-\mathrm{O})\right]^{2+} .3 \mathrm{CH}_{3} \mathrm{CN}\left(\mathbf{2}^{\prime}\right)$, where $\mathbf{L}^{\mathbf{2}^{\prime}}=\mathbf{L}^{2}-1 \mathrm{H}_{\mathrm{Ph}}$, was formed. In the symmetric bis( $\mu$-hydroxo)diiron(III) dication, the $\mathrm{OL}^{2}{ }^{2}$ ligands are coordinated trans to each other in the hypodentate fashion. Each iron centre adopts a distorted octahedral geometry, and the tripod coordinates in the $\kappa^{4}-(\mathrm{N}, \mathrm{O})$ mode, by involving three nitrogen atoms, N1, N2 and $\mathrm{N} 3$, and one oxygen (O3) of a phenoxo group. Two oxygen atoms of hydroxo groups complete the coordination sphere of iron atoms by sharing the two octahedrons. In this geometry, one substituted pyridyl unit remotes from the coordination centre. All Fe-N distances are longer than $2.1 \AA$ (see Fig. 5 caption) and lie in the expected range for high-spin ferric derivatives. ${ }^{81}$ The $\mathrm{N} 1$ and $\mathrm{O} 3$ atoms on one hand, and the $\mathrm{O}^{\prime}$ and $\mathrm{N} 1^{\prime}$ atoms on the other hand occupy apical positions with $\mathrm{N}$-Fe-O $\square 157^{\circ}$. Furthermore, the $\mathrm{Fe}_{2} \mathrm{O}_{2}(\mathrm{H})$ core in the dication of $2^{\prime}$ imposes the angle $\mathrm{O}-\mathrm{Fe}-\mathrm{O}=78.40(16)^{\circ}$ more acute than the $\mathrm{Cl}-\mathrm{Fe}-\mathrm{Cl}=101.54(10)^{\circ}$ in the parent neutral compound 2, then allowing a tetradentate coordination of the $\mathrm{OL}^{\mathbf{2}^{\prime}}$ ligand. The iron-oxygen (phenoxo) $_{\text {distance, }} 1.8864(4) \AA$, suggests a relatively strong Fe1-O3 bond. Thus the oxidation of $\mathbf{2}$ by $\mathrm{H}_{2} \mathrm{O}_{2}$, leading to the formation of 2', implies the activation of one C$\mathrm{H}$ bond of a phenyl group and the concomitant oxidation of the related ligand via the loss of a hydrogen, that is replaced by an oxygen atom. Usually, upon reaction of dichloroiron (II) species with molecular dioxygen, hydrogen peroxide or organic peroxides, $\mu$-oxo dinuclear complexes are obtained..$^{82}$ Here, such a reaction gives rise to a bis- $\mu$-hydroxo compound with $\mathrm{Fe}-\mathrm{OH}$ distances of $2.022 \AA$, that are comparable with those found in similar hexacoordinating iron (II/III) complexes. ${ }^{78}$ The Fe1-O-Fe1' angle $\left(101.60(15)^{\circ}\right)$ is close to that observed in this type of compound $\left(\square 104.70^{\circ}\right)$, as well as the Fe1-Fe1' distance (3.082 $\AA$ ) that is comparable with the values reported in the literature. ${ }^{78}$ Such a distance is short and cannot exclude an interaction between the two iron atoms which differs from those found in $\mu$-oxo diiron(II) complexes having TPA ligands (3.456-3.575 ̊̊), where the two iron centres are formally nonbonded. ${ }^{41,45,46,66,81,83}$ In the latter compounds the Fe-O-Fe angles are quite less acute $\left(\square 166.4^{\circ}\right)$ than that in the dication of $\mathbf{2}^{\prime}$. The dianion $\left[\mathrm{Fe}\left(\mathrm{Cl}_{3}\right)_{2}(\mu-\mathrm{O})\right]^{2+}$ is present in $\mathbf{2}^{\prime}$ as the counter-ion. The dianion has already been reported in the literature as a counter-ion in the manganese(II) ${ }^{84}$ and iron(II) ${ }^{85}$ complexes, $\left[\mathrm{Mn}\left(\mathrm{C}_{3} \mathrm{H}_{7} \mathrm{NO}\right)\right]\left[\left(\mathrm{FeCl}_{3}\right)_{2}(\mu-\mathrm{O})\right]$, where $\mathrm{C}_{3} \mathrm{H}_{7} \mathrm{NO}=$ dimethylformamide, and $\left[\mathrm{Fe}(1,10-\text { phen })_{3}\right]\left[\left(\mathrm{FeCl}_{3}\right)_{2}(\mu-\mathrm{O})\right]$. In all of these complexes, each iron (III) centre lies in a pseudotetrahedral environment. Recently, Tinberg and Lippard have shown that two hydroxide ligands bridge the iron atoms, which are separated by $3.1 \AA$, in the diiron(III) resting state of the enzyme $(\mathrm{MMOHx}){ }^{17}$ Interestingly, the $\left\{\mathrm{Fe}(\mu-\mathrm{OH})_{2} \mathrm{Fe}\right\}$ core in the dication of 2' displays similar geometrical data to those observed in this enzyme, with two bridging hydroxide ligands and a Fe" ${ }^{\prime \prime \prime}-\mathrm{Fe}^{\text {III }}$ distance equal to $3.082 \AA$ A (see Fig. 5). 


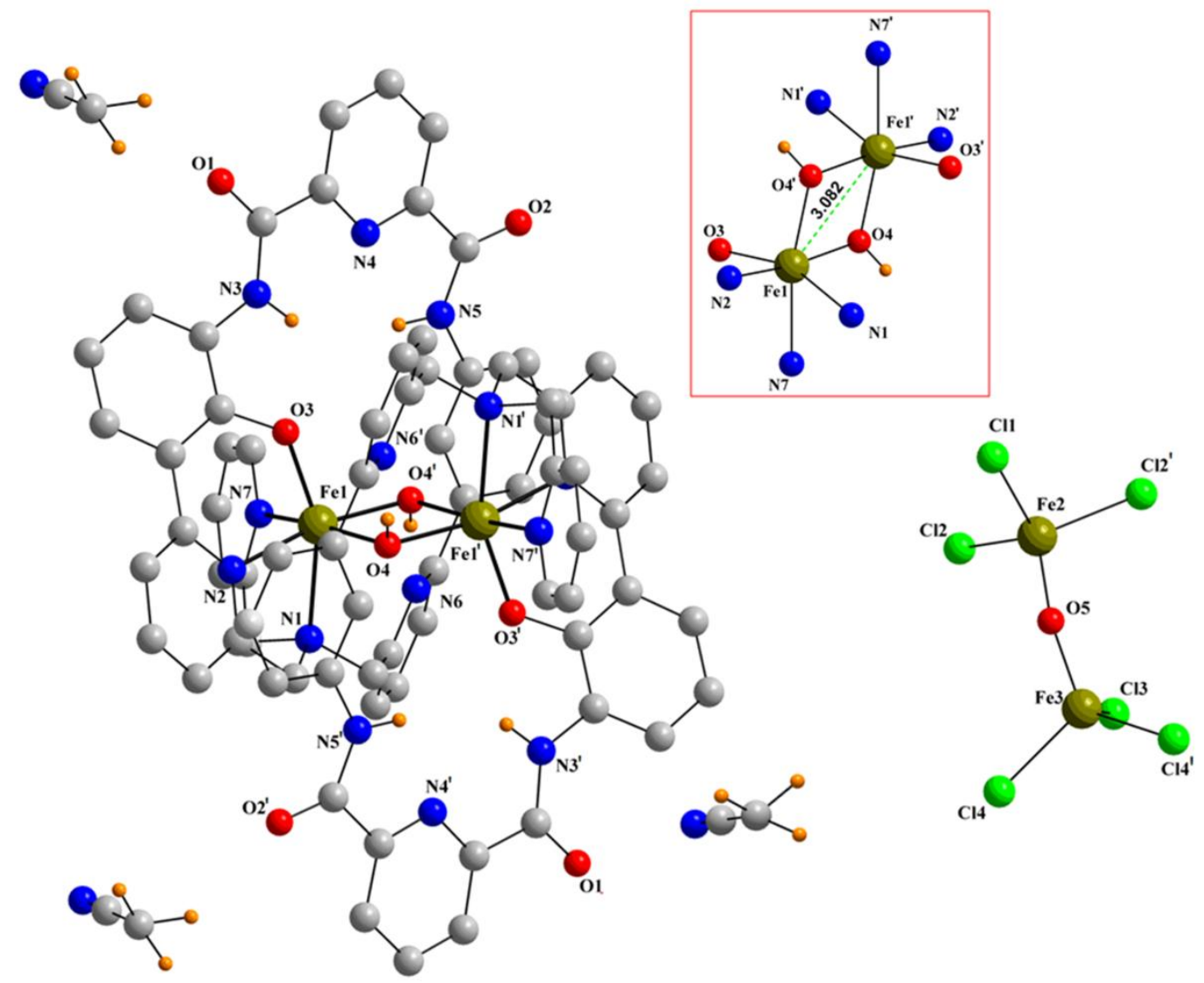

Fig. 5. "Ball and stick" model of complex $\mathbf{2}^{\prime},\left[\left\{\mathrm{Fe}\left(\mathrm{OL}^{2}\right)\right\}_{2}(\mu-\mathrm{OH})_{2}\right]^{2+},\left[\left(\mathrm{FeCl}_{3}\right)_{2}(\mu-\mathrm{O})\right]^{2+} .3 \mathrm{CH}_{3} \mathrm{CN}$, showing the atom labelling scheme. Thermal ellipsoids are plotted at $10 \%$ probability. Hydrogen atoms have been omitted for clarity (except the hydroxido ones). Selected bond distances ( $\AA$ ) and angles $\left({ }^{\circ}\right)$ in the dication: Fe1-Fe1' $=3.082(5)$, Fe1- $\mathrm{N} 1=2.241(5)$, Fe1$\mathrm{N} 2=2.142(4)$, Fe1-N7=2.170(4), Fe1-O3=1.886(4), Fe1-O4=1.955(4), Fe1-O4'=2.022(4), N3-H3N=0.869(18), N5-H5N=0.856(12), O4-H4w=0.830(2), N1-Fe1-N2=75.96(17), N1-Fe1$\mathrm{N} 7=76.65(17), \mathrm{N} 1-\mathrm{Fe} 1-03=157.35(17), \mathrm{N} 2-\mathrm{Fe} 1-\mathrm{N} 7=97.20(17), \mathrm{N} 2-\mathrm{Fe} 1-\mathrm{O}=88.13(17), \mathrm{N} 7-\mathrm{Fe} 1-\mathrm{O}=89.73(17), \mathrm{N} 7-\mathrm{Fe} 1-\mathrm{O} 4=93.30(16), \mathrm{N} 7-\mathrm{Fe} 1-04^{\prime}=168.63(15), \mathrm{N} 1-\mathrm{Fe} 1-\mathrm{O}=98.20(16)$, N1-Fe1-O4'=96.66(16), N2-Fe1-O4=166.38(17), N2-Fe1-04'=89.95(16), O3-Fe1-O4=100.60(16), O3-Fe1-O4'=99.37(15), Fe1-O4-Fe1'=101.60(15), Fe1-O4-H4w=103.00(4), Fe1'-04$\mathrm{H} 4 \mathrm{w}=121.00(4)$. Selected bond distances $(\AA)$ and angles $\left({ }^{\circ}\right)$ in the dianion: Fe2-O5=1.790(6), Fe2-Cl=2.233(2), Fe3-05=1.754(5), Fe3-Cl3=2.225, Fe- $\mathrm{Cl} 4 / 4^{\prime}=2.204(4), \mathrm{Fe} 2-05-$ $\mathrm{Fe} 3=140.40(3), \quad \mathrm{Cl} 1-\mathrm{Fe} 2-\mathrm{Cl} 2=109.21(6), \quad \mathrm{Cl} 1-\mathrm{Fe} 2-\mathrm{Cl} 2^{\prime}=109.21(6), \quad \mathrm{Cl} 1-\mathrm{Fe} 2-05=110.61(10), \quad \mathrm{Cl} 2-\mathrm{Fe} 2-\mathrm{Cl} 2^{\prime}=108.59(9), \quad \mathrm{Cl} 3-\mathrm{Fe} 3-\mathrm{Cl} 4=110.14(7), \quad \mathrm{Cl} 3-\mathrm{Fe} 3-\mathrm{Cl} 4^{\prime}=110.14(7), \quad \mathrm{Cl} 4-\mathrm{Fe}-$ $\mathrm{Cl} 4^{\prime}=104.18(13), \mathrm{Cl} 3-\mathrm{Fe} 3-\mathrm{O} 5=107.80(19), \mathrm{Cl} 4-\mathrm{Fe} 3-\mathrm{O}=112.29(12), \mathrm{Cl} 4^{\prime}-\mathrm{Fe} 3-\mathrm{O} 5=112.29(12)$.

\section{Reactivity of complexes 1-4 towards m-CPBA}

The reactivity of the complex 3 towards $\mathrm{m}$-CPBA was also investigated by UV-Vis spectroscopy at low and room temperatures in acetonitrile. Room temperature studies did not allow the characterization of any transient species, probably due the high rate of the reaction, as shown by the change of the colour of the solution (red to green). However, as shown in Fig. 6 , the addition of oxidant to a solution of $\mathbf{3}$ at $40^{\circ} \mathrm{C}$ led to the formation of two new bands at $\lambda_{\max }=709 \mathrm{~nm}$ $\left(\varepsilon=335 \mathrm{M}^{-1} \mathrm{~cm}^{-1}\right)$ and $520 \mathrm{~nm}\left(\varepsilon=610 \mathrm{M}^{-1} \mathrm{~cm}^{-1}\right)$. While the former decreased progressively with time $\left(t_{1 / 2}=13 \mathrm{~min}\right)$, the latter kept on rising to attain a steady state value. These results are reminiscent of that obtained for the analogous $\left[\mathrm{Fe}^{\text {II }} \text { (TPA) }\left(\mathrm{CH}_{3} \mathrm{CN}\right)_{2}\right]^{2+}$ complex. ${ }^{86}$ Indeed, a transient species was detected at $\lambda_{\max }=724 \mathrm{~nm}\left(\varepsilon \approx 300 \mathrm{M}^{-1} \mathrm{~cm}^{-1}\right)$ upon addition of peracetic acid at low temperature $\left(-40^{\circ} \mathrm{C}\right)$. This absorption band was ascribed to a $\mathrm{d}$-d transition within the
$\left[\mathrm{Fe}^{\mathrm{IV}}(\mathrm{O})(\mathrm{TPA})\right]^{2+}$ complex. Similarly, the reaction of $[\mathrm{Fe}$ "16MeTPA) $\left.\left(\mathrm{CH}_{3} \mathrm{CN}\right)_{2}\right]^{2+}$ with peracetic acid at low temperature yielded a new species which displayed an absorption band at $\lambda_{\max }=770 \mathrm{~nm}\left(\varepsilon \approx 300 \mathrm{M}^{-1} \mathrm{~cm}^{-1}\right)$, ascribed to a $\mathrm{Fe}(\mathrm{IV})$-oxo species. ${ }^{87}$ Hence, these results suggest that the reaction of complex 3 with m-CPBA lead possibly to the transient species $\left[\mathrm{Fe}^{\mathrm{IV}}(\mathrm{O})\left(\mathbf{L}^{1}\right)\right]^{2+}$, as shown in Scheme 4. 


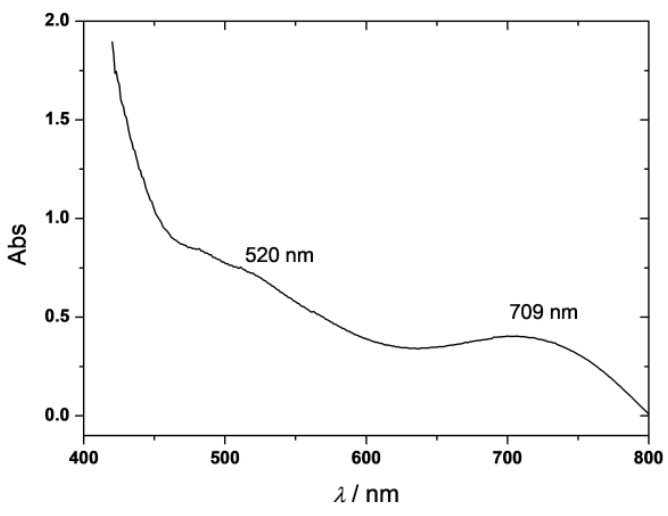

Fig. 6. UV-Vis spectrum of $3(2.5 \mathrm{mM})$ in $\mathrm{CH}_{3} \mathrm{CN}$ after addition of 1.2 molar eq. of $\mathrm{m}$ CPBA. (Optical path: $5 \mathrm{~mm}$ ) at $-40^{\circ} \mathrm{C}$.

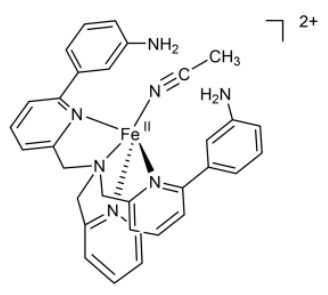

$\left[\mathrm{Fe}^{\prime \prime}\left(\mathrm{L}^{1}\right)\left(\mathrm{CH}_{3} \mathrm{CN}\right)\right]^{2+}$

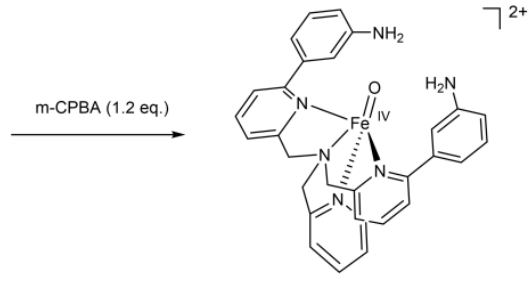

$\left[\mathrm{Fe}^{\mathrm{IV}}(\mathrm{O})\left(\mathrm{L}^{1}\right)\right]^{2+}$
Scheme 4. Reactivity of complex 3 with m-CPBA, leading to the formation of $\left[\mathrm{Fe}^{\mathrm{IV}}(\mathrm{O})\left(\mathrm{L}^{1}\right)\right]^{2+}$.

\section{Comparative catalytic activity of 1-4 for cyclohexane oxidation}

\section{Catalytic oxidation of cyclohexane by $\mathrm{H}_{2} \mathrm{O}_{2}$}

The reaction studies with $\mathrm{H}_{2} \mathrm{O}_{2}$ were performed by adding hydrogen peroxide (1 eq.) to a solution of cyclohexane (1 eq.) containing 0.001 eq. of iron(II) catalyst, as depicted on Scheme
5. The experiments were carried out first in absence and then in presence of acetic acid ( $\mathrm{ACOH}, 0.5$ eq.) in order to enhance the yield of the reaction. Indeed, $\mathrm{AcOH}$ is well known for inhibiting the decomposition of hydrogen peroxide into water and dioxygen. Moreover, it has been proposed that acetic acid could promote the heterolytic (vs homolytic) cleavage of the $\mathrm{O}-\mathrm{O}$ bond in $\mathrm{Fe}^{\mathrm{III}}$-hydroperoxo adducts, leading to reactive high-valent $\mathrm{Fe}^{\mathrm{V}}$-oxo species. ${ }^{79,88}$<smiles>CC1CCCCC1</smiles>

$(100 \%)$

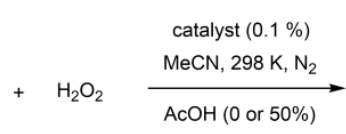

$(100 \%)$

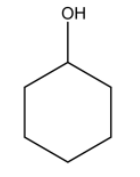<smiles>O=C1CCCCC1</smiles>

K [catalyst $=$ complex $1,2,3$ or 4 ]

Scheme 5. Catalyzed oxidation of cyclohexane by 1, 2, 3 or 4 in presence of $\mathrm{H}_{2} \mathrm{O}_{2}$ with/without acetic acid $(\mathrm{AcOH})$, leading to the formation of cyclohexanol $(\mathrm{A})$ and cyclohexanone (K). Percentages indicate the molar equivalents vs. cyclohexane.

Data obtained from GC analysis for the different catalysts 1-4 are gathered in Table 5. Considering the turnover number, $[\mathrm{A}] /[\mathrm{K}]$ and yield values, it appears clearly that the topology of the TPA-based ligand, $\mathbf{L}^{\mathbf{1}}$ or $\mathbf{L}^{\mathbf{2}}$, significantly impacts the catalytic properties. As shown in Fig. 7, the yield and turnover numbers for the production of both $A$ and $K$ are much enhanced with the complexes $\mathbf{2}$ and $\mathbf{4}$, by ca. a three-fold factor, than for $\mathbf{1}$ and $\mathbf{3}$. In particular, the TONs are greater (between 6 and 9) in absence of acetic acid. The selective oxidation towards $\mathrm{A}$ or $\mathrm{K}$ species seems however poorly affected by the nature of the complex or by the concentration in $\mathrm{AcOH}$.

Table 5. Data for the catalytic oxidation of cyclohexane by $1,2,3$ or 4 in presence of $\mathrm{H}_{2} \mathrm{O}_{2}$

\begin{tabular}{|c|c|c|c|c|c|c|}
\hline Catalyst & AcOH (eq.) & TON (A) & TON (K) & $\begin{array}{c}\text { TON (A) + TON } \\
(\mathrm{K})\end{array}$ & {$[\mathrm{A}] /[\mathrm{K}]$} & Yield (\%) \\
\hline \multirow[t]{2}{*}{1} & 0 & 1.6 & 1.9 & 3.5 & 0.83 & 0.1 \\
\hline & 0.5 & 0.3 & 0.4 & 0.7 & 0.74 & $<0.1$ \\
\hline \multirow[t]{2}{*}{2} & 0 & 5.7 & 8.9 & 14.6 & 0.64 & 0.8 \\
\hline & 0.5 & 2.9 & 3.6 & 6.5 & 0.80 & 0.4 \\
\hline \multirow[t]{2}{*}{3} & 0 & 0.5 & 0.4 & 0.9 & 1.29 & $<0.1$ \\
\hline & 0.5 & 0.5 & 0.4 & 0.9 & 1.10 & $<0.1$ \\
\hline \multirow[t]{2}{*}{4} & 0 & 6.2 & 7.4 & 13.6 & 0.83 & 0.8 \\
\hline & 0.5 & 0.3 & 0.3 & 0.6 & 1.00 & $<0.1$ \\
\hline
\end{tabular}


Table 6. Data for the catalytic oxidation of cyclohexane by $\mathbf{1 , 2 , 3}$ or $\mathbf{4}$ in presence of $\mathrm{m}$-CPBA.

\begin{tabular}{|c|c|c|c|c|c|c|}
\hline Catalyst & AcOH (eq.) & TON (A) & TON (K) & $\begin{array}{c}\text { TON (A) + TON } \\
(\mathrm{K})\end{array}$ & {$[\mathrm{A}] /[\mathrm{K}]$} & Yield (\%) \\
\hline \multirow[t]{2}{*}{1} & 0 & 4.7 & 5.4 & 10.1 & 0.87 & 0.4 \\
\hline & 0.5 & 10.4 & 3.9 & 14.3 & 2.66 & 0.6 \\
\hline \multirow[t]{2}{*}{2} & 0 & 24.4 & 5.4 & 29.8 & 4.52 & 1.8 \\
\hline & 0.5 & 6.1 & 4.5 & 10.6 & 1.36 & 0.6 \\
\hline \multirow[t]{2}{*}{3} & 0 & 2.6 & 1.1 & 3.7 & 2.35 & 0.2 \\
\hline & 0.5 & 3.1 & 1.7 & 4.8 & 1.84 & 0.2 \\
\hline \multirow[t]{2}{*}{4} & 0 & 1.7 & 0.5 & 2.2 & 3.40 & 0.1 \\
\hline & 0.5 & $\mathrm{a}$ & $\mathrm{a}$ & $\mathrm{a}$ & $a$ & $\mathrm{a}$ \\
\hline
\end{tabular}

${ }^{\text {a }}$ No data available

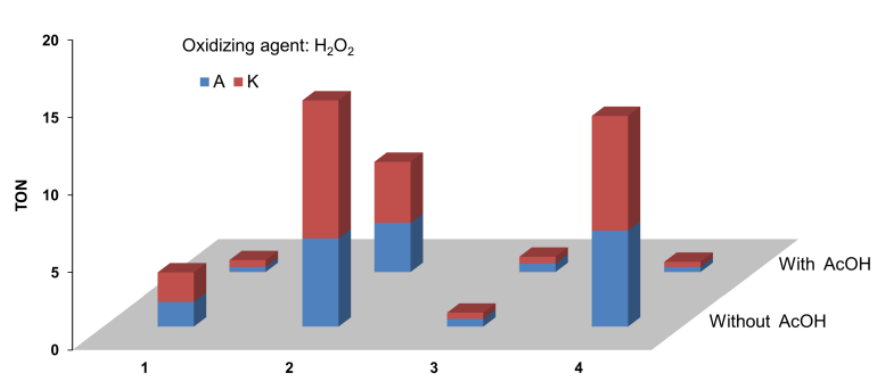

Fig. 7. Representative histogram for the turnover number for the catalytic oxidation of cyclohexane into cyclohexanol ( $\mathrm{A}$, blue) and cyclohexanone (K, red) by $\mathbf{1}, \mathbf{2}, \mathbf{3}$ or $\mathbf{4}$ in presence of $\mathrm{H}_{2} \mathrm{O}_{2}$.

\section{Catalytic oxidation of cyclohexane by m-CPBA}

The catalytic properties of complexes 1-4 were also investigated by using $\mathrm{m}$-CPBA as oxidizing agent. As shown in Scheme 6, m-CPBA (0.1 eq.) was gently added to a solution of cyclohexane (1 eq.) containing the iron(II) catalyst ( 0.001 eq.). As for $\mathrm{H}_{2} \mathrm{O}_{2}$, the influence of $\mathrm{AcOH}$ ( 0.1 eq.) on the yield of the reaction was investigated.

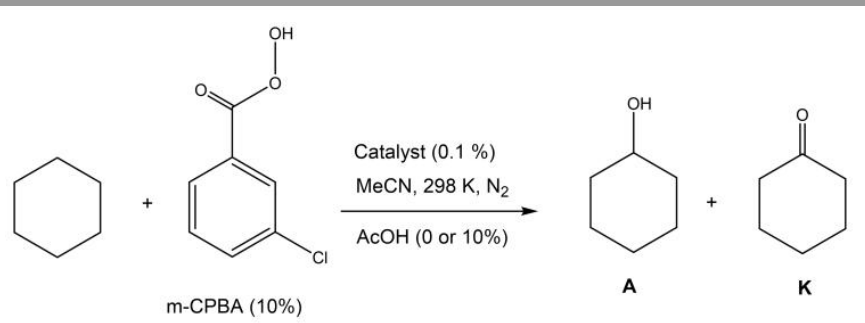

[Catalyst $=$ complex $1,2,3$ or 4 ]

Scheme 6. Catalyzed oxidation of cyclohexane by 1, 2, 3 or 4 in presence of m-CPBA with/without acetic acid $(\mathrm{ACOH})$, leading to the formation of cyclohexanol $(\mathrm{A})$ and cyclohexanone (K). Percentages indicate the molar equivalents vs. cyclohexane.

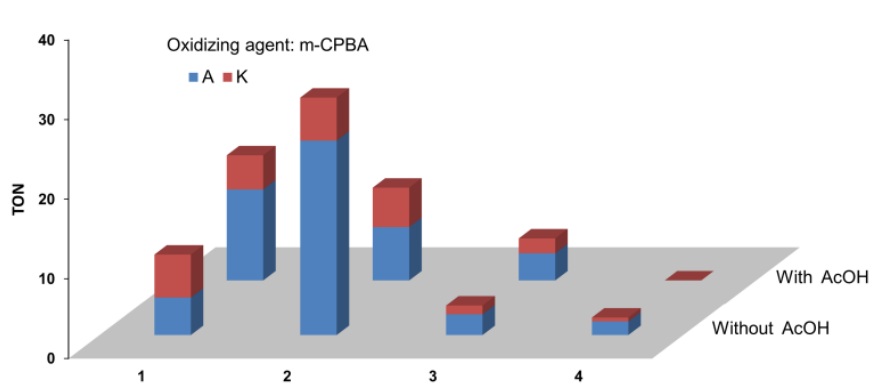

Fig. 8. Representative histogram for the total turnover number for the catalytic oxidation of cyclohexane into cyclohexanol (A, blue) and cyclohexanone (K, red) by 1, 2, $\mathbf{3}$ or $\mathbf{4}$ in presence of $\mathrm{m}$-CPBA.

The Fig. 8 displays the turnover numbers obtained for the reaction yielding both $A$ and $K$ species. The best TON values were obtained for complexes $\mathbf{1}$ and $\mathbf{2}$ (see Table 6 for data), indicating that the presence of the chloride ligand significantly enhanced the oxidation reaction with this oxidizing agent. In particular, the complex 2 reached $c a$. 30 TONs in absence of $\mathrm{AcOH}$. Moreover, it is noteworthy that the selectivity (A vs K) of the catalyzed reaction, compared to the results obtained with $\mathrm{H}_{2} \mathrm{O}_{2}$. Here, the complex 2 displayed a remarkable 4.52 ratio for $[A] /[K]$ (Table 6 ), together with relatively moderate reaction yield. This selectivity dropped to 1.36 when acetic acid was used as co-factor.

\section{Discussion on coordination chemistry of complexes 1-4}

Solid state and solution characterizations have shown that the iron(II) ion is mainly pentacoordinated in the TPA core for all high-spin complexes 1, 2, 3 and 4, whatever the nature of the counter-ion ( $\mathrm{Cl}^{-}$or OTf). The $\mathrm{Fe}^{\prime \prime}$ centre is bound to the nitrogen atom of the tertiary amine and two $\mathrm{N}$ atoms of two different pyridyl groups (one substituted and one unsubstituted), the coordination sphere being completed by either one or two counter-ions, one or two molecules of solvent or the remaining substituted pyridyl group. The solid state structures obtained from X-ray diffraction analysis for $\mathbf{2}$ and $\mathbf{3}$ indicate a geometrical pattern in-between square-based pyramidal (SBP) and trigonal-bipyramidal (TBP), the TPA core being essentially coordinating in a tridentate fashion. More specifically, the macrocyclic complex $\mathbf{2}$ display one free substituted pyridyl group, the structure being too rigid to 
accommodate the coordination of all $\mathrm{N}$-atoms of the TPA system. To better account for the effect of the ligand topology, the complexes 1-4 can be compared to their previously reported TPA and $\mathrm{Ph}_{2}$ TPA analogues. ${ }^{40}$

Solid state analysis of $\left[\mathrm{Fe}^{\prime \prime} \mathrm{Cl}_{2}\right.$ (TPA)] showed that the metal ion is hexacoordinated in a pseudo-octahedral geometry with two equatorial chloride ions (Scheme 7). The substitution of $\mathrm{H}$ atom by phenyl groups on two of the three pyridyl moieties, leading to $\left[\mathrm{Fe}^{\mathrm{I}} \mathrm{Cl}_{2}\left(\mathrm{~L}^{\mathrm{a}}\right)\right]$, induces a strong modification of the coordination sphere (Scheme 7). Indeed, X-ray diffraction analysis showed that the tripodal $\mathrm{Ph}_{2}$ TPA core coordinates in a tridentate mode in presence of chloride ions, because of steric repulsions, as observed in other $\alpha$-disubstituted TPA complexes. ${ }^{40}$ In addition, the geometry around the Fe(II) centre is no longer pseudo-octahedral but rather trigonal bipyramidal. These coordination features are conserved in acetonitrile. Hence, on the basis of NMR, UV-Vis and conductivity measurements, complexes $\mathbf{1}$ and $\mathbf{2}$ display similar structural properties to $\left[\mathrm{Fe}^{\mathrm{II}} \mathrm{Cl}_{2}\left(\mathrm{~L}^{\mathrm{a}}\right)\right]^{2+}$ in acetonitrile, the iron(II) centre being pentacoordinated as depicted in Scheme 7 .

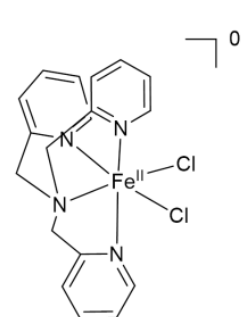

$\left[\mathrm{Fe}^{\| \prime} \mathrm{Cl}_{2}(\mathrm{TPA})\right]$

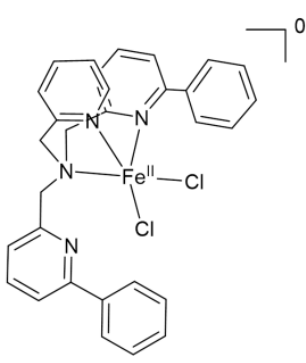

$\left[\mathrm{Fe}^{\| l} \mathrm{Cl}_{2}\left(\mathrm{~L}^{\mathrm{a}}\right)\right]$

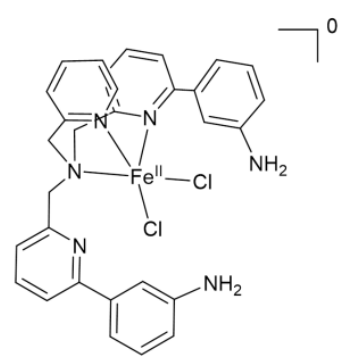

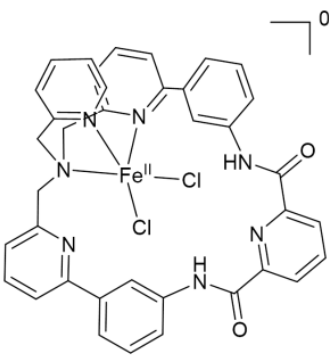

2

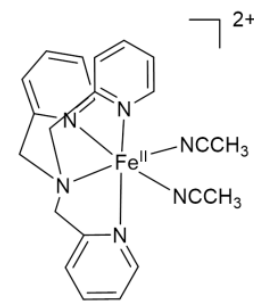

$\left[\mathrm{Fe} \text { "I (TPA) }\left(\mathrm{CH}_{3} \mathrm{CN}\right)_{2}\right]^{2+}$

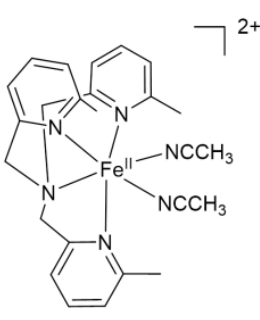

$\left[\mathrm{Fe}^{\prime \prime}\left(\mathrm{Me}_{3} \mathrm{TPA}\right)\left(\mathrm{CH}_{3} \mathrm{CN}\right)_{2}\right]^{2+}$

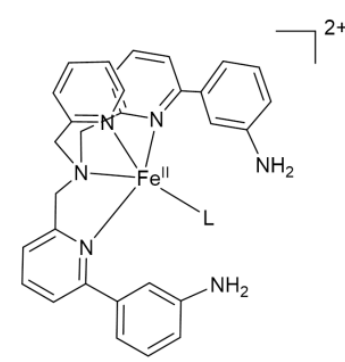

$3\left(\mathrm{~L}=\mathrm{CH}_{3} \mathrm{CN}, \mathrm{H}_{2} \mathrm{O}\right)$

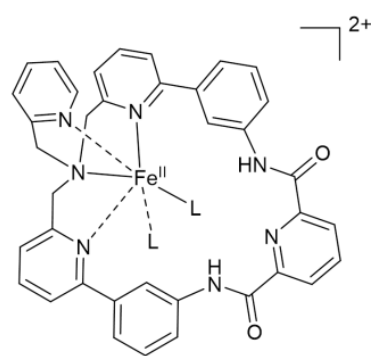

$4\left(\mathrm{~L}=\mathrm{CH}_{3} \mathrm{CN}, \mathrm{H}_{2} \mathrm{O}\right)$

Scheme 7. Proposed structures for complexes 1, 2, 3 and $\mathbf{4}$ and their analogues in acetonitrile.

As for its bis-chloride analogue, [Fe"(TPA) $\left.\left(\mathrm{CH}_{3} \mathrm{CN}\right)_{2}\right]^{2+}$ is characterized at solid state by an octahedral geometry around the ferrous centre (Scheme 7), the two nitrile ligands being coordinated in cis-position. ${ }^{89}$ These structural features are kept when the solid is dissolved in acetonitrile. When the TPA core is substituted by the 6-Me $\mathrm{MPA}_{3}$ TPA ligand, the resulting complex, [Fe"(6-Me $\left.\left.{ }_{3} \mathrm{TPA}\right)\left(\mathrm{CH}_{3} \mathrm{CN}\right)_{2}\right]^{2+}$, displays also a 6coordinated pseudo-octahedral structure thus indicating that the methyl substituting groups do not induce significant steric constraints (Scheme 7). ${ }^{89}$ The same conclusion was obtained with the more sterically-hindered complex $\left[\mathrm{Fe} \text { "(BQPA)(OTf) }{ }_{2}\right]^{+} .{ }^{90}$ Conversely, both solid state and solution analyses of complexes 3 and 4 are indicative of 4 or 5coordinated species in a distorted TBP geometry. In particular, only one nitrile molecule is coordinated to the iron centre for the complex 3 , probably as a result of steric effects by aminophenyl groups. For complex 4, the absence of signal at 120 ppm in the ${ }^{1} \mathrm{H}$ NMR spectrum suggests that the unsubstituted pyridyl is not bound to $\mathrm{Fe}^{\prime \prime}$, thus leading possibly the coordination of the two substituted pyridyl groups and/or solvent. Such structure remains however hypothetical without clear experimental evidence.

\section{Discussion on the catalytic properties of complexes 1-4}

Non-hemic iron(II) complexes of general formula $L F$ II $\mathrm{n}(\mathrm{L}=\mathrm{N}$ ligand, $\mathrm{X}=$ solvent or anion; $\mathrm{n}=1,2$ ) are well known for reacting with $\mathrm{H}_{2} \mathrm{O}_{2}$ to yield $\mathrm{Fe}^{\prime \prime \prime}(\mathrm{OOH})$ species. ${ }^{2,7,79}$ Depending on the nature of $\mathrm{L}$ and $\mathrm{X}$, the resulting hydroperoxo can either react with a hydrogenated substrate $(\mathrm{RH}$, pathway a, Scheme 8 ) or evolves towards $\mathrm{Fe}^{\mathrm{V}}(\mathrm{O})$ (pathway b) or $\mathrm{Fe}^{\mathrm{IV}}(\mathrm{O})$ (pathway $\mathrm{c}$ ) species through heterolytic or homolytic $\mathrm{O}-\mathrm{O}$ bond cleavage. Hence, these three transient species can potentially oxidize hydrogenated substrates. Notably, numerous studies have emphasized that oxidizing $\mathrm{Fe}^{\mathrm{V}}(\mathrm{O})(\mathrm{OH})$ species could be 
obtained through a water-assisted process for complexes bearing strong field tetradentate aminopyridine ligands and two cis-labile sites. ${ }^{2,79}$ Here, we have shown that the reaction of 2 with $\mathrm{H}_{2} \mathrm{O}_{2}$ leads possibly to the formation of the hydroperoxo complex according to UV-Vis spectroscopic data. In absence of substrate, the complex evolves towards the bis $(\mu-\mathrm{OH})$ species 2' bearing a phenoxo moiety (Scheme 8 ). Such intramolecular aromatic hydroxylation was previously observed for [Fe" $\left.(6-\mathrm{PhTPA})\left(\mathrm{CH}_{3} \mathrm{CN}\right)_{2}\right]^{2+}$ in presence of ${ }^{\mathrm{t}} \mathrm{BuOOH}$ in acetonitrile and was ascribed to the formation of a $\mathrm{Fe}(\mathrm{IV})$ oxo species upon homolytic O-O bond breaking of the generated [Fe"(6-PhTPA) $\left.\left(\mathrm{OO}^{\mathrm{t}} \mathrm{Bu}\right)\right]^{2+}$ adduct. $^{82}$ It was also described for other mononuclear complexes. ${ }^{91,92}$

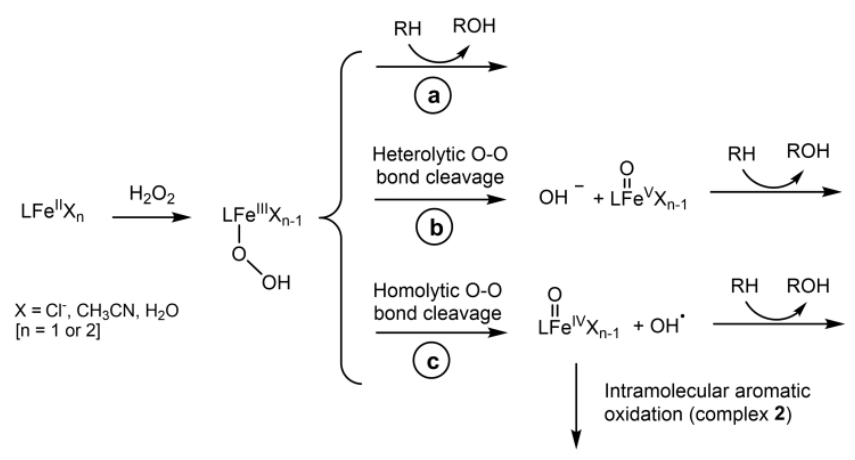

Scheme 8. Possible mechanistic pathways for the reaction of complexes 1, 2, 3 and 4 with $\mathrm{H}_{2} \mathrm{O}_{2}$, in presence or not of cyclohexane $(\mathrm{RH})$, according to the catalytic studies.

Under catalytic conditions (1000 eq. of $\mathrm{H}_{2} \mathrm{O}_{2}$ and substrate vs catalyst), all complexes lead to the formation of cyclohexanol (A) and cyclohexanone $(\mathrm{K})$ with low yields $(<1 \%)$ and low TONs. In particular, the ratio of produced alcohol over ketone $(\mathrm{A} / \mathrm{K})$ is close to 1 , thus strongly suggesting that a Fenton-like reaction for which the effective oxidant is an hydroxyl radical $\mathrm{OH}^{*}$, and not an iron-oxygen adduct. ${ }^{7,90,93,94}$ This is consistent with the studies without substrate: according to Scheme 8 , pathways $\mathrm{c}$ leads to the formation of a $\mathrm{Fe}(\mathrm{IV})$-oxo species and a hydroxyl radical. While the former can perform the intramolecular aromatic hydroxylation, the latter is involved in exogenous cyclohexane oxidation. It is noticeable that both macrocyclic complexes $\mathbf{2}$ and $\mathbf{4}$ are more efficient than $\mathbf{1}$ and $\mathbf{3}$, and that the counter ion ( $\mathrm{Cl}^{-}$or OTf) does not significantly influence the results (Figure 7). This would indicate, that the rate-determining step is not the formation of the putative iron- hydroperoxo species but merely the homolytic O-O bond cleavage. The higher activity of $\mathbf{2}$ can be explained by the probable higher redox potential according to the electrochemical studies (see Table 4). Addition of acetic acid to promote the pathway $b$ was not conclusive since the TON substantially decreased (Figure 7). Probably, the formation of the $\mathrm{Fe}^{\mathrm{V}}(\mathrm{O})$ is not enhanced for steric reasons, and the acetic acid then plays the role of substrate (vs $\mathrm{OH}^{\circ}$ ), thus inhibiting cyclohexane oxidation.

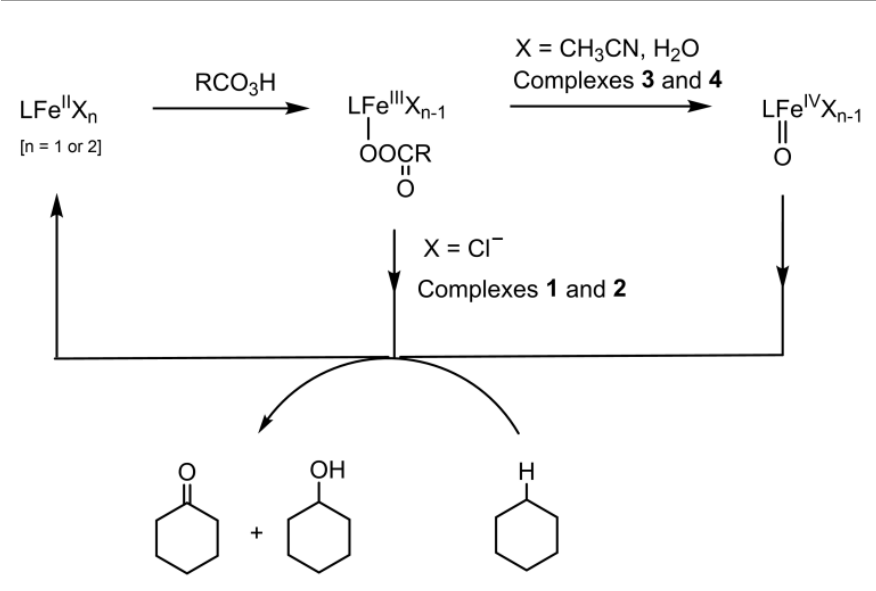

Scheme 9. Two proposed mechanistic pathways for the oxidation of cyclohexane by $\mathbf{1}$, $\mathbf{2 , 3}$ or $\mathbf{4}$ in presence of $m$-CPBA according to the catalytic studies.

The reaction between $\mathrm{m}$-CPBA and iron(II) complexes is well known for leading to the direct formation of iron(IV) and iron(V) -oxo species through homolytic and heterolytic O-O bond cleavage of the m-CPBA-iron adduct. ${ }^{95}$ Here, we have shown that complex $\mathbf{2}$ presumably yields to the transient species $\left[\mathrm{Fe}^{\mathrm{IV}}(\mathrm{O})\left(\mathrm{L}^{1}\right)\right]^{2+}$ by reaction with $\mathrm{m}$-CPBA in acetonitrile (Scheme 9). Moreover, our studies clearly demonstrate that complexes $\mathbf{1}$ and $\mathbf{2}$ behave differently to $\mathbf{3}$ and $\mathbf{4}$ for the catalytic oxidation of cyclohexane in presence of $m$-CPBA. As shown in Fig. 8 and Table 6, complexes 1 and $\mathbf{2}$ perform the oxidation of cyclohexane into cyclohexanol and cyclohexanone with $A / K>1$, whereas complexes 3 and 4 do essentially not. Intuitively, these discrepancies can be associated to the effect of the presence/absence of chloride ion(s) bound to the iron centre. Such effect was previously reported for the reaction of different iron-porphyrin complexes in organic solvents. Indeed, Nam et al. showed that strong-donating chloride ligand could enhance the reactivity of the $\mathrm{Fe}(\mathrm{III})-\mathrm{OOC}(\mathrm{O}) \mathrm{R}$ adduct toward cyclohexane. ${ }^{95} \mathrm{~A}$ contrario, weak-donating triflate anion led to the formation of $\mathrm{Fe}(\mathrm{IV})$-oxo species by homolytic $\mathrm{O}-\mathrm{O}$ bond breaking. Such scenario could be envisaged for complexes 1-4. As shown in Scheme 9, the putative Fe' (OOCOR) adduct may react with cyclohexane or evolve towards a $\mathrm{Fe}^{\mathrm{IV}}$-oxo complex, depending on the nature of the exogenous bound ligand $\left(X=\mathrm{Cl}^{-}\right.$ , $\mathrm{CH}_{3} \mathrm{CN}$ or $\mathrm{H}_{2} \mathrm{O}$ ). Thus, chloride ligands would promote the reaction of the acylperoxo species with cyclohexane while triflate ones would yield poorly reactive $\mathrm{Fe}(\mathrm{IV})$-oxo species. Such metal-based oxidation (and not $\mathrm{OH}^{\circ}$ ) could be confirmed by the $A / K$ ratio obtained for the catalytic studies, which varies between 0.9 and 4.5. Notably, the best results for catalysis have been obtained with complex 2 . These results are consistent with electrochemical data which indicate a relatively high oxidation potential for the macrocyclic complex (Table 4).

\section{Conclusions}

In summary, we have synthesized and characterized four mononuclear iron(II) complexes, on the basis of the non- 
macrocylic and macrocylic ligands $\mathbf{L}^{\mathbf{1}}$ and $\mathbf{L}^{\mathbf{2}}$, respectively. Our studies provide evidences that all synthesized complexes are high-spin and mainly pentacoordinated at solid state and in acetonitrile. The $\mathrm{Fe}^{\text {" }}$ centre is coordinated by three or four nitrogen atoms of the TPA core, the coordination sphere being completed by counter-anions ( $\mathrm{Cl}^{-}$, OTf $)$or solvent molecules $\left(\mathrm{H}_{2} \mathrm{O}, \mathrm{CH}_{3} \mathrm{CN}\right)$. The penta-coordinated feature is probably due to steric constraints between the phenyl groups. The reaction of the different complexes with oxidizing agents $\left(\mathrm{H}_{2} \mathrm{O}_{2}\right.$ and $\mathrm{m}$ CPBA) leads presumably to the formation of hydroperoxo and oxo adducts as shown by UV-Vis spectroscopy. The catalytic studies of the oxidation of cyclohexane suggest a Fenton-like reaction involving a hydroxyl radical for all complexes when using $\mathrm{H}_{2} \mathrm{O}_{2}$ as oxidant. Noteworthy, a different scenario involving a metal-based reaction takes place when using $\mathrm{m}$ CPBA. Hence, our studies demonstrate that two factors impact significantly the catalytic properties for the oxidation of cyclohexane. The first one is the macrocyclic design of the TPAderived ligand which leads to higher catalytic activity. Such effect could result from the high redox potential of the complex 2 vs non macrocyclic analogues, as shown by electrochemical studies. The second parameter is the nature of the exogenous ligand (chloride, $\mathrm{H}_{2} \mathrm{O}, \mathrm{CH}_{3} \mathrm{CN}$ ) in solution which can control the reaction pathway. From this basis, future work will aim at introducing a second metal ion with the macrocyclic ligand $\mathbf{L}^{\mathbf{2}}$ in order to mimic the dinuclear centre in the active site of sMMO.

\section{Acknowledgments}

The authors acknowledge the University of Bretagne Occidentale (UBO) for PhD grant (M. Ayad). Dr. Francois Michaud is thanked for X-Ray diffraction analysis. The Agence Nationale de la Recherche (ANR-11-BS07-0024) is thanked for financial support.

\section{Conflicts of interest}

There are no conflicts to declare.

\section{Notes and references}

1 S. Friedle, E. Reisner and S. J. Lippard, Chem. Soc. Rev., 2010, 39, 2768-2779.

2 I. Gamba, Z. Codolà, J. Lloret-Fillol and M. Costas, Coord. Chem. Rev., 2017, 334, 2-24.

3 W. Wang, A. D. Liang and S. J. Lippard, Acc. Chem. Res., 2015, 48, 2632-2639.

4 T. L. Poulos, Chem. Rev., 2014, 114, 3919-3962.

5 I. G. Denisov, T. M. Makris, S. G. Sligar and I. Schlichting, Chem. Rev., 2005, 105, 2253-2277.

6 B. Meunier, S. P. de Visser and S. Shaik, Chem. Rev., 2004 104, 3947-3980.

7 A. C. Lindhorst, S. Haslinger and F. E. Kühn, Chem. Commun. 2015, 51, 17193-17212.

8 M. Costas, Coord. Chem. Rev., 2011, 255, 2912-2932.

9 A. J. Jasniewski and L. Que, Jr., Chem. Rev., 2018, 118, 25542592.
10 E. I. Solomon, T. C. Brunold, M. I. Davis, J. N. Kemsley, S.-K. Lee, N. Lehnert, F. Neese, A. J. Skulan, Y.-S. Yang and J. Zhou, Chem. Rev., 2000, 100, 235-350.

11 E. I. Solomon, K. M. Light, L. V. Liu, M. Srnec and S. D. Wong, Acc. Chem. Res., 2013, 46, 2725-2739.

12 E. I. Solomon, S. Goudarzi and K. D. Sutherlin, Biochemistry, 2016, 55, 6363-6374.

13 M. Costas, M. P. Mehn, M. P. Jensen and L. Que Jr., Chem. Rev., 2004, 104, 939-986.

14 E. G. Kovaleva and J. D. Lipscomb, Nat. Chem. Biol., 2008, 4 186-193.

15 S. M. Barry and G. L. Challis, ACS Catal., 2013, 3, 2362-2370.

16 D. J. Ferraro, L. Gakhar and S. Ramaswamy, Biochem. Biophys. Res. Commun., 2005, 338, 175-190.

17 C. E. Tinberg and S. J. Lippard, Acc. Chem. Res., 2011, 44 280-288.

18 A. Trehoux, J.-P. Mahy and F. Avenier, Coord. Chem. Rev., 2016, 322, 142-158.

19 R. Banerjee, Y. Proshlyakov, J. D. Lipscomb and D. A. Proshlyakov, Nature, 2015, 518, 431-434.

20 H.-F. Hsu, Y. Dong, L. Shu, V. G. Young and L. Que, J. Am. Chem. Soc., 1999, 121, 5230-5237.

21 G. Xue, R. De Hont, E. Münck and L. Que Jr., Nat. Chem. 2010, 2, 400-405.

22 J.-U. Rohde, J.-H. In, M. H. Lim, W. W. Brennessel, M. R. Bukowski, A. Stubna, E. Münck, W. Nam and L. Que Jr., Science, 2003, 299, 1037-1039.

23 W. Nam, Y.-M. Lee and S. Fukuzumi, Acc. Chem. Res., 2014, 47, 1146-1154.

24 W. Nam, Acc. Chem. Res., 2015, 48, 2415-2423.

25 J. Cho, S. Jeon, S. A. Wilson, L. V. Liu, E. A. Kang, J. J. Braymer M. H. Lim, B. Hedman, K. O. Hodgson, J. S. Valentine, E. I. Solomon and W. Nam, Nature, 2011, 478, 502-505.

26 A. Thibon, J. England, M. Martinho, V. G. Young, J. R. Frisch, R. Guillot, J.-J. Girerd, E. Münck, L. Que and F. Banse, Angew. Chem. Int. Ed., 2008, 47, 7064-7067.

27 A. Company, L. Gómez, X. Fontrodona, X. Ribas and M Costas, Chem. Eur. J., 2008, 14, 5727-5731.

28 I. Prat, J. S. Mathieson, M. Güell, X. Ribas, J. M. Luis, L. Cronin and M. Costas, Nat. Chem., 2011, 3, 788-793.

29 T. Inomata, K. Shinozaki, Y. Hayashi, H. Arii, Y. Funahashi, T. Ozawa and H. Masuda, Chem. Commun., 2008, 392-394.

30 J. B. Strautmann, S. Dammers, T. Limpke, J. Parthier, T. P. Zimmermann, S. Walleck, G. Heinze-Bruckner, A. Stammler, H. Bogge and T. Glaser, Dalton Trans., 2016, 45, 3340-3361.

31 M. Kodera, M. Itoh, K. Kano, T. Funabiki and M. Reglier, Angew. Chem. Int. Ed., 2005, 44, 7104-7106.

32 M. Sekino, H. Furutachi, K. Tasaki, T. Ishikawa, S. Mori, S. Fujinami, S. Akine, Y. Sakata, T. Nomura, T. Ogura, T. Kitagawa and M. Suzuki, Dalton Trans., 2016, 45, 469-473.

33 M. Kodera, T. Tsuji, T. Yasunaga, Y. Kawahara, T. Hirano, Y. Hitomi, T. Nomura, T. Ogura, Y. Kobayashi, P. K. Sajith, Y. Shiota and K. Yoshizawa, Chem. Sci., 2014, 5, 2282-2292.

34 M. Kodera, S. Ishiga, T. Tsuji, K. Sakurai, Y. Hitomi, Y. Shiota, P. K. Sajith, K. Yoshizawa, K. Mieda and T. Ogura, Chem. Eur. J., 2016, 22, 5924-5936.

35 L. H. Do and S. J. Lippard, J. Am. Chem. Soc., 2011, 133 10568-10581.

36 L. H. Do and S. J. Lippard, J. Inorg. Biochem., 2011, 105, 17741785

37 F. Wang, S. Becker, M. A. Minier, A. Loas, M. N. Jackson and S. J. Lippard, Inorg. Chem., 2017, 56, 11050-11058.

38 M. Mitra, J. Lloret-Fillol, M. Haukka, M. Costas and E. Nordlander, Chem. Commun., 2014, 50, 1408-1410.

39 M. Puri and L. Que, Jr., Acc. Chem. Res., 2015, 48, 2443-2452.

40 D. Mandon, A. Machkour, S. Goetz and R. Welter, Inorg. Chem., 2002, 41, 5364-5372. 
41 A. Machkour, D. Mandon, M. Lachkar and R. Welter, Inorg. Chem., 2004, 43, 1545-1550.

42 A. Machkour, D. Mandon, M. Lachkar and R. Welter, Inorg. Chim. Acta, 2005, 358, 839-843.

43 N. K. Thallaj, A. Machkour, D. Mandon and R. Welter, New J. Chem., 2005, 29, 1555-1558.

44 L. Benhamou, M. Lachkar, D. Mandon and R. Welter, Dalton Trans., 2008, 6996-7003.

45 N. K. Thallaj, O. Rotthaus, L. Benhamou, N. Humbert, M. Elhabiri, M. Lachkar, R. Welter, A. M. Albrecht-Gary and D. Mandon, Chem. Eur. J., 2008, 14, 6742-6753.

46 L. Benhamou, A. Machkour, O. Rotthaus, M. Lachkar, R. Welter and D. Mandon, Inorg. Chem., 2009, 48, 4777-4786.

47 A. Wane, N. K. Thallaj and D. Mandon, Chem. Eur. J., 2009, 15, 10593-10602.

48 H. Jaafar, R. Louis and D. Mandon, Inorg. Chim. Acta, 2011, 366, 147-153.

49 H. Jaafar, B. Vileno, A. Thibon and D. Mandon, Dalton Trans., 2011, 40, 92-106.

50 D. Mandon, H. Jaafar and A. Thibon, New J. Chem., 2011, 35, 1986-2000.

51 D. Huang and R. H. Holm, J. Am. Chem. Soc., 2010, 132, 46934701.

52 X. Zhang, D. Huang, Y. S. Chen and R. H. Holm, Inorg. Chem., 2012, 51, 11017-11029.

53 M. R. Halvagar, B. Neisen and W. B. Tolman, Inorg. Chem., 2013, 52, 793-799.

54 S. M. Nelson and J. Rodgers, J. Chem. Soc. A, 1968, 272-276.

55 W. Offermann and F. Vögtle, Angew. Chem. Int. Ed., 1980, 19, 464-465.

56 Z. Tyeklar, R. R. Jacobson, N. Wei, N. N. Murthy, J. Zubieta and K. D. Karlin, J. Am. Chem Soc., 1993, 115, 2677-2689.

57 C.-L. Chuang, O. dos Santos, X. Xu and J. W. Canary, Inorg. Chem., 1997, 36, 1967-1972.

58 D. Mandon, A. Nopper, T. Litrol and S. Goetz, Inorg. Chem., 2001, 40, 4803-4806.

59 M. P. Jensen, S. J. Lange, M. P. Mehn, E. L. Que and L. Que, Jr., J. Am. Chem. Soc., 2003, 125, 2113-2128.

60 C. Piguet, J. Chem. Educ., 1997, 74, 815.

61 G. A. Bain and J. F. Berry, J. Chem. Educ., 2008, 85, 532.

62 G. Shedrix, SHELXS97, 1997, University of Gottingen, Germany.

63 L. J. Farrugia, J. Appl. Crystallogr., 1999, 32, 837-838.

64 A. Diebold and K. S. Hagen, Inorg. Chem., 1998, 37, 215-223.

65 A. Machkour, N. K. Thallaj, L. Benhamou, M. Lachkar and D. Mandon, Chem. Eur. J., 2006, 12, 6660-6668.

66 L. Benhamou, H. Jaafar, A. Thibon, M. Lachkar and D. Mandon, Inorg. Chim. Acta, 2011, 373, 195-200.

67 L. Benhamou, A. Thibon, L. Brelot, M. Lachkar and D. Mandon, Dalton Trans., 2012, 41, 14369-14380.

68 A. Thibon, L. Karmazin-Brelot and D. Mandon, Eur. J. Inorg. Chem., 2013, 2013, 1118-1122.

69 N. K. Thallaj, P. Y. Orain, A. Thibon, M. Sandroni, R. Welter and D. Mandon, Inorg. Chem., 2014, 53, 7824-7836.

70 A. W. Addison, T. N. Rao, J. Reedijk, J. van Rijn and G. C. Verschoor, J. Chem. Soc., Dalton Trans., 1984, 1349-1356.
71 W. J. Geary, Coord. Chem. Rev., 1971, 7, 81-122.

72 T. J. Hubin, J. M. McCormick, S. R. Collinson, M. Buchalova, C. M. Perkins, N. W. Alcock, P. K. Kahol, A. Raghunathan and D. H. Busch, J. Am. Chem Soc., 2000, 122, 2512-2522.

73 D. B. Rorabacher, Chem. Rev., 2004, 104, 651-697.

74 H. Nagao, N. Komeda, M. Mukaida, M. Suzuki and K. Tanaka, Inorg. Chem., 1996, 35, 6809-6815.

75 C.-I. Chuang, K. Lim, Q. Chen, J. Zubieta and J. W. Canary, Inorg. Chem., 1995, 34, 2562-2568.

76 R. J. Butcher and A. W. Addison, Inorg. Chim. Acta, 1989, 158, 211-215.

77 G. J. Britovsek, J. England and A. J. White, Inorg. Chem., 2005, 44, 8125-8134.

78 D. M. Kurtz, Chem. Rev., 1990, 90, 585-606.

79 S. M. Hölzl, P. J. Altmann, J. W. Kück and F. E. Kühn, Coord. Chem. Rev., 2017, 352, 517-536.

80 A. J. Simaan, S. Döpner, F. Banse, S. Bourcier, G. Bouchoux, A. Boussac, P. Hildebrandt and J.-J. Girerd, Eur. J. Inorg. Chem., 2000, 2000, 1627-1633.

81 J. Wang, M. S. Mashuta, Z. Sun, J. F. Richardson, D. N Hendrickson and R. M. Buchanan, Inorg. Chem., 1996, 35, 6642-6643.

82 S. J. Lange, H. Miyake and L. Que, J. Am. Chem Soc., 1999 121, 6330-6331.

83 P. Gomez-Romero, E. H. Witten, W. M. Reiff, G. Backes, J. Sanders-Loehr and G. B. Jameson, J. Am. Chem Soc., 1989, 111, 9039-9047.

84 E. N. Chygorin, S. R. Petrusenko, V. N. Kokozay, Y. O. Smal, I. V. Omelchenko and O. V. Shishkin, Acta Crystallogr. Sect. E Struct. Rep. Online, 2011, 67, m1563-1564.

85 C. Ling, L. Song and X. Wang, Acta Crystallogr. Sect. E Struct. Rep. Online, 2011, 67, m1232-1233.

86 M. H. Lim, J. U. Rohde, A. Stubna, M. R. Bukowski, M. Costas, R. Y. Ho, E. Munck, W. Nam and L. Que, Jr., Proc. Natl. Acad. Sci. U.S.A., 2003, 100, 3665-3670.

87 T. K. Paine, M. Costas, J. Kaizer and L. Que, Jr., J. Biol. Inorg. Chem., 2006, 11, 272-276.

88 J. Serrano-Plana, F. Acuna-Pares, V. Dantignana, W. N. Oloo, E. Castillo, A. Draksharapu, C. J. Whiteoak, V. MartinDiaconescu, M. G. Basallote, J. M. Luis, L. Que, Jr., M. Costas and A. Company, Chem. Eur. J., 2018, 24, 5331-5340.

89 Y. Zang, J. Kim, Y. Dong, E. C. Wilkinson, E. H. Appelman and L. Que, J. Am. Chem Soc., 1997, 119, 4197-4205.

90 K. Chen and L. Que, J. Am. Chem. Soc., 2001, 123, 6327-6337.

91 Y. Mekmouche, S. Ménage, C. Toia-Duboc, M. Fontecave, J. B. Galey, C. Lebrun and J. Pécaut, Angew. Chem. Int. Ed., 2001, 40, 949-952.

92 Y. Mekmouche, S. Ménage, J. Pécaut, C. Lebrun, L. Reilly, V. Schuenemann, A. Trautwein and M. Fontecave, Eur. J. Inorg. Chem., 2004, 2004, 3163-3171.

93 E. P. Talsi and K. P. Bryliakov, Coord. Chem. Rev., 2012, 256, $1418-1434$.

94 A. Thibon, V. Jollet, C. Ribal, K. Senechal-David, L. Billon, A. B. Sorokin and F. Banse, Chem. Eur. J., 2012, 18, 2715-2724.

95 W. Nam, M. H. Lim, S. K. Moon and C. Kim, J. Am. Chem. Soc., 2000, 122, 10805-10809. 